\title{
Adoption of fintech services: role of saving and borrowing mechanisms
}

\author{
Babak Naysary $^{\mathrm{a}}$, Ruth Tacneng ${ }^{\mathrm{b}}$, Amine Tarazi ${ }^{\mathrm{bc}}$ \\ ${ }^{a}$ INTI International University, Faculty of Business, Nilai, Malaysia \\ ${ }^{\text {b } U n i v e r s i t e ́ ~ d e ~ L i m o g e s, ~ L A P E, ~} 5$ rue Félix Eboué, 87031 Limoges Cedex 1, France \\ ${ }^{c}$ Institut Universitaire de France (IUF), 1 rue Descartes, 75231 Paris Cedex 05, France
}

This version: September 2, 2021

\begin{abstract}
This paper investigates the relationship between an individual's saving and borrowing practices and his/her propensity to use fintech services. More particularly, we examine whether having multiple saving and borrowing channels increases a person's likelihood to participate in online funding platforms, and use robo-advisors. Using a sample of over 2000 respondents to a survey we conducted in Malaysia, our main results indicate that individuals who save and borrow via multiple channels, and through external conduits, are more likely to use fintech services than their counterparts. This is consistent with the view that individuals who use multiple saving and borrowing conduits are more likely to perform mental accounting, a concept which is commonly used by fintech companies to facilitate personal wealth management. Further, our findings reveal that among respondents with multiple saving channels, those who put less importance on trust in financial products, and consider financial returns essential, are the most likely users of fintech services. Overall, our findings offer new insights by providing a better understanding of the factors that foster the use of fintech services.

Keywords: fintech, P2P lending platforms, crowdfunding, robo-advisors, trust, alternative lending JEL Classification: G2, G23, G51
\end{abstract}




\section{Introduction}

In recent years, fintech firms and their technology-driven alternative financial solutions have been increasingly tapped to overcome the barriers to financial access and credit provision (Costa and Ehrbeck, 2015; Demir et al., 2020), and to enchance personal wealth management. Such firms are viewed as key drivers of financial inclusion, innovation, and efficiency because of their potential to increase access to finance (Buckley et al., 2019), reduce the costs of financial intermediation (Philippon, 2019), improve consumer welfare, reduce behavioral biases with regard to wealth management (D'Acunto et al., 2019), and increase GDP growth (Shofawati, 2019). Moreover, distrust in banks in the wake of the 2007/2008 Global Financial Crisis has enabled investors and borrowers to tap alternative investment opportunities such as funding firms in online peer-to-peer (P2P) lending and crowdfunding platforms (Saiedi et al., 2020), which offer higher yield than bank deposits. In addition, the changing market dynamics and evolving consumer preferences have also helped propel fintech lending growth and exerted pressure on incumbent financial institutions to adopt fintech approaches or to establish alliances with the new entrants. Recognizing the proliferation of fintech services worldwide, as well as their importance for growth and implications on financial stability, the IMF and the World Bank established the Bali Fintech Agenda in 2018 (IMF, 2018), which contains important policy recommendations and framework proposals linked with fintech advances.

Due to the deemed capacity of fintech companies to reduce the credit gap to micro and small firms, increase formal financial services outreach especially to unbanked individuals, and provide alternative algorithm-based solutions to personal wealth management, there is growing interest to investigate the factors that make individuals adopt or avoid fintech services. In spite of platforms' efforts to increase transparency and to provide risk ratings for each loan or project, information asymmetry coupled with limited financial capability are often seen as important challenges faced by potential investors in P2P lending and crowdfunding platforms. It is, hence, not surprising that P2P lending investors have employed various bidding strategies to deal with moral hazard problems and lack of financial expertise, such as herding behavior (Herzenstein et al., 2011; Lee and Lee, 2012), evaluation of borrowers' social networks (Lin et al., 2013; Freedman and Jin, 2017) and lenders' geographical proximity from borrowers (Lin and Viswanathan, 2016). In terms of the drivers of fintech participation in online P2P lending and crowdfunding, the literature has documented extrinsic motivating factors such as adherence to social norms (Deci and Ryan, 2010), monetary incentives (Pierrakis and Collins, 2013), and reciprocity (Colombo et al., 2015). Moreover, intrinsic drivers, especially in the case of crowdfunding include pro-social and altruistic behavior (Guidici et al., 2018; Cholakova and Clarysse, 2015), sensation-seeking attitude and excitement to participate in P2P lending (Demir et al., 2021; Daskalakis and Yue, 2018), and distrust in banks (Saiedi et al., 2020). In terms of the use of personal wealth management fintech solutions, such as the use of robo-advisors, several studies find perceived complexity and effectiveness (PwC, 2019), age and gender (David and Sade, 2019; Todd and Seay, 2020), self-assessed financial experience (Hohenberger et al., 2019), income, and subjective and objective financial knowledge (Fan and Chatterjee, 2020; Todd and Seay, 2020), and social influence and trust (PwC, 2019; Gan et al., 2021) as determinants of robo-advisor adoption.

In this paper, we mainly explore the roles played by borrowing and saving practices on the propensity to use fintech services. More particularly, we study whether individual borrowing and saving channel diversity and his/her reliance on specific borrowing and saving channels, such as traditional banks, are associated with higher likelihood to use online funding platforms and robo-advisors. To our knowledge, this is the first study that analyzes the link between borrowing and saving mechanisms and fintech adoption. Furthermore, we also study whether factors individuals consider important in a 
financial product -trust, ease of use, type and quality of services provided, financial returns, and prestige, influence their likelihood to adopt fintech services. Moreover, our paper also contributes to the literature by analyzing how financial service preferences affect the saving channel diversity-fintech adoption relationship. Jünger and Mietzner (2020) argue that users' willingness to adopt fintech services goes beyond offering cheaper, more appealing solutions. Moreover, compared with traditional financial institutions such as banks, fintech firms lack customer loyalty, brand recognition and client trust (FSB, 2019). To the extent that trust and reliability of financial services may be an important barrier to fintech adoption, it might be less crucial especially for those who rely on diverse saving channels.

Our empirical analysis, which extends the literature on the determinants of fintech adoption, is based on the online survey responses of around 2000 individuals in Malaysia. The survey mainly probes individuals' use of various fintech services, and borrowing and saving practices. In addition, the survey data includes information about respondents' socio-economic characteristics, as well as barriers to the use of fintech instruments. Malaysia is an ideal setting to study participation in online fintech funding platforms and use of robo-advisors because it has increasingly embraced fintech opportunities. Moreover, it is the first South East Asian country to introduce regulations in P2P lending platforms. In recent years, the Securities Commission Malaysia (SC) has increased efforts to enhance investment access by tapping into digital innovative solutions. Aside from increasing the maximum amount that equity crowdfunding platforms (ECF) may raise and widening the scope of eligibility of potential ECF issuers, the SC has also launched a secondary trading framework for online funding platforms, which provides investors with an exit mechanism. As of 2020, around 1403 P2P lending platforms and ECF issuers have raised over RM630 million (approximately, US \$153 million), with the aim to raise funds for business expansion and to finance firms' working capital needs. In recent years, the SC has also introduced frameworks which promote and support licensing and regulatory functions for roboadvisors (Gan et al., 2021). Moreover, the Central Bank of Malaysia, the Bank Negara Malaysia (BNM), has also set up various innovation facilitators in recent years. It established a regulatory sandbox in 2016, which aims to make essential financial services more accessible and efficient ${ }^{1}$, and an industry fintech accelerator and digital finance innovation hub in 2018, in partnership with the United Nations Capital Development Fund (UNCDF) and the Malaysian Digital Economy Corporation (MDEC), to promote inclusive finance. In 2020, several institutions, such as the MDEC, have announced partnerships with crowdfunding operators to help face Covid-19 challenges.

Our main findings indicate that individuals who use multiple saving and borrowing channels are more likely to use fintech services than non-savers and non-borrowers, and those who only rely on a single saving or borrowing channel. We purport that, individuals who have access to multiple borrowing and saving channels are more likely to keep track of their financial activities, and use the mental accounting principle than their counterparts when managing their wealth. Thus, they seem to find it easier to expand their investment ventures to new entrants such as online funding platforms and use automated personal wealth management tools such as robo-advisors, which facilitates mental accounting (Zhang and Sussman, 2018) and narrow bracketing. In addition, such individuals may be able to discern better the advantages and the added value of fintech solutions to personal wealth management than those who rely on a single saving and borrowing channel and those who do not save nor borrow. We also find respondents who rely on external borrowing channels to have higher likelihood of using fintech services than their counterparts. Moreover, we find strong evidence showing that those who use

${ }^{1}$ Source : https://www.bnm.gov.my/-/ financial-technology-regulatory-sandbox-framework 
various channels to save are more likely to use robo-advisors than those who solely rely on traditional banks for their savings, thus giving credence to the link between mental accounting and the use of fintech services. We perform robustness checks by examining the impact of saving and borrowing channel diversity on the degree of fintech service use and by exploring how factors savers consider important in a financial service influence the link between saving channel diversity and the likelihood to invest in online funding platforms and use robo-advisors. The findings indicate that among respondents who use multiple saving channels, those who consider monetary returns important, and those who put less importance on trust and ease of use, to be more likely to invest in P2P lending platforms and use robo-advisors. Consistent with the literature, we find older respondents, and those who have low incomes and lower educational attainment to be less likely to use fintech services.

The rest of the paper is organized as follows. Section 2 presents a review of the recent literature on the adoption of fintech services, followed by the results of our survey in section 3 . We present our empirical framework and discuss our findings in section 4. We check the robustness of our results in section 5. Finally, we conclude in section 6.

\section{Review of Related Literature and Research Focus}

Most studies that investigate the drivers of fintech participation or adoption (Chuang et al., 2016; Hong et al., 2020; Hu et al., 2019; Jünger and Mietzner, 2020; Singh et al., 2020; Tun-Pin et al., 2019) base their analysis on the Technology Acceptance Model (TAM) by Davis (1989). They either focus on the perceived usefulness of the technology and consumer comfort, or extend the TAM by including reliability, trust and perceived risk, which are crucial concerns related to digital banking activities. Moreover, some studies highlight the importance of other driving factors in influencing the use of fintech services, such as financial literacy (Jünger and Mietzner, 2020), price value (Carlin et al., 2017; Senyo and Osabutey, 2020), tech-savviness and geographical location of users (Hong et al., 2020), brand image and government support (Hu et al., 2019), generation, gender and information (Carlin et al., 2017), distrust in banks (Saiedi et al., 2020), as well as intrinsic factors such as excitement and sensation-seeking behavior (Daskalakis and Yue, 2018). We note that the majority of these studies rely on responses to surveys directly collected from individuals or on customer data from online funding platforms.

\subsection{Recent literature on the drivers of participation in online funding platforms}

The ubiquity of fintech credit services in recent years and the disruptive structural change brought forth by alternative online funding solutions have led to various studies evaluating the factors influencing the adoption of these services. Xie et al. (2019) indicate that due to the lack of a mature credit information system and high transaction costs, banks are less willing to lend money to small businesses and individuals, creating a credit gap for these groups in the economy. Online funding platforms, hence, are viable and innovative alternatives to traditional financial service providers, catering to various businesses including small firms.

Trust, reliability and perceived risk are often cited as important factors determining the adoption of fintech services. With regard to P2P lending platforms, Yang and Lee (2016) point out that platform transparency is positively related to the level of Chinese investors' trust. In the case of Malaysia, using the technology acceptance model (TAM), Thaker et al. (2019) highlight that trust is the only significant factor determining the potential use of P2P lending services. They explain that due to tight regulation 
and supervision by the Central Bank (BNM), concerns regarding security and risk related to the P2P lending and equity crowdfunding sector do not determine individuals' fintech participation in the segment. Moreover, some studies find that fintech participants seem to be more concerned about financial factors such as interest rates, loan cost and flexibility in repayments (Rosavina et al., 2019). Interestingly, in the case of crowdfunding, investors seem to care more about the design of project campaigns (Guirado et al. 2018). Furthermore, Thies et al. (2016) study the impact of personality traits on the success of crowdfunding projects and find openness and agreeableness expressed in project descriptions and videos to have a strong influence on investors' decision to participate in the campaigns and to disseminate them on social media. Moreover, Saiedi et al. (2020) examine whether distrust in banks is an important factor affecting fintech participation in online funding platforms. Examining the U.S., they find that individuals who reside in states that highly distrust banks are more likely to participate in P2P lending and to allocate more to P2P loans, particularly to borrowers seeking small loans or to those who are underserved by banks. Moreover, Lewis et al. (2020) find political culture as an important driver of crowdfunding adoption. They find crowdfunding to be less popular and more slowly legitimated in conservative regions in the U.S. compared to liberal regions, which are more receptive to these platforms. Crowdfunding issuers also cite plagiarism risk as an influential factor in the acceptance of crowdfunding. According to Jaziri and Miralam (2019), fundraisers are often concerned about their projects being copied, which may adversely affect their funding success.

\subsection{Recent literature on factors influencing the use of robo-advisors}

Relative to factors influencing online funding platform participation, the determinants of roboadvisory adoption have been less studied in the literature. Robo-advisors provide automated, algorithm-based solutions to personal wealth management. In contrast to human financial advisors, robo-advisors act without behavioral biases in assisting investors to better manage their wealth, and usually offer lower fees (D’Acunto et al., 2019, Fisch et al., 2018).

The literature documents various factors affecting the adoption of robo-advisory services. Using online and computerized laboratory experiments, David and Sade (2019) find variations in the willingness to pay for financial advice and readiness to adopt robo-advisory services according to individual demographic characteristics such as age and gender. Their results indicate younger participants aged 20 to 30 years old, and men to have higher propensity to pay for and trust algorithmbased financial advice. Using U.S. survey data on individuals with non-retirement investment accounts, Todd and Seay (2020) also find younger individuals, with low to middle class incomes, and those who have low objective investment knowledge to be more likely to use robo-advisors. Consistent with the results of Fan and Chatterjee (2020), they also find those with subjective investment knowledge to be positively linked to robo-advisory use. Moreover, a PwC (2019) study on the use of robo-advisors using online survey responses of their Italian employees, finds social influence, trust and perception of its complexity and effectiveness to be correlated with respondents' attitudes towards robo-advisors. Gan et al. (2021) find similar results in Malaysia. They find performance expectancy, social influence and trust in robo-advisors to be positively linked with robo-advisory adoption by consumers. Hohenberger et al. (2019) highlight the influence of self-assessed financial experience through expected positive or negative emotions from its use, on the willingness of individuals to use roboadvisors. In addition, they find self-enhancement motives such as the possibility of wealth accumulation to play crucial roles in mitigating the adverse impact of anticipated negative emotions linked with robo-advisors, on their willingness to use these types of services. 


\subsection{Individual borrowing and saving channels and the use of fintech services}

An individual's financial behavior, particularly his borrowing and saving practices, may or may not influence his/her inclination to use fintech services.

Several studies in the literature exploring how individuals manage and keep track of their financial activities emphasize the role of mental accounting (Zhang and Sussman, 2018; Thaler, 1980, 1985, 1999) and narrow bracketing (Tversky and Kahneman, 1981; Rabin and Weizsäcker, 2009) when making financial decisions. Thaler (1985) suggests that an individual is sensitive to local temporal budget constraints and thus, makes decisions subject to time- and category-specific budget constraints. Indeed, households typically set funds or budget according to the intended use or type of expenditure, such as for travel, weekly gas budget, building an emergency fund, and investment. Moreover, they have the tendency to match specific fund sources to each mental account (Hastings and Shapiro, 2013), differentiating for example, the budget sets depending on whether changes in income are due to a windfall gain or an expected increase in the regular income (Milkman and Beshears, 2009). Meanwhile, narrow bracketing theories assume that individuals divide complex decision problems into several parts and make decisions on each part separately. Mental accounting and narrow bracketing theories are in contrast to standard economic theory which predicts that mental accounts or fund categorization should not affect financial behavior because their boundaries are only notionally set. Indeed, mental accounting and narrow bracketing violates the fungibility principle which presumes that money is substitutable for another, and thus income and wealth composition, labels and categorizations, is irrelevant for consumption (Abeler and Marklein, 2016). Advances in financial technology in recent years, for example, the capability to track payment and expenses, and transform personal and household finance management, enable mental accounting (Zhang and Sussman, 2018) and narrow bracketing. We argue that individuals who keep various saving channels, such as setting aside cash and keeping bank savings accounts, are those who are more likely to perform mental accounting than those who only save through one channel and more particularly compared to those who do not save at all. We purport that this also makes them more likely to use fintech services more than others.

Moreover, borrowers or clients who rely on an exclusive saving or borrowing channel may be different from those who take overlapping loans and use various channels to save (Green and Liu, 2021). In addition, depending on the length of the creditor-borrower and saver-debtor relationship, the loan and saving terms and conditions may vary. McIntosh and Wydick (2005) argue that economic agents who contract multiple loans tend to be myopic because credit terms often offered when more lenders enter the credit market are often disadvantageous due to increasing information asymmetry, especially in an environment where credit information sharing is limited or unavailable. Moreover, multiple borrowing may also be perceived as a sign of financial development and could be inevitable especially for those who need funds to finance new investment opportunities or for those who need to diversify their income generating activities. We note, though, that while it may be costly to enter another saving or lending relationship, individuals may still be likely to engage in such relationships if new financial service providers are offering low cost or better-quality service, thus, justifying the need to shift or tap other saving and borrowing channels.

In addition, individuals who use different saving and borrowing channels may be at a better position to analyze a complex set of information, and are more familiar with different terms and conditions as well as the advantages of different financial options. Thus, they may be more adept at analyzing the expected gains from using fintech services. Examining, however, different sets of information, 
especially those related to new financial services are not necessarily favorable for individuals who use a lot of borrowing and saving channels, because it is a laborious and grueling undertaking to analyze a wide set of options. Thus, not being able to gauge expected gains and expected costs may deter them from adopting the use of fintech services.

We, hence, purport that individuals who have multiple lending and saving relationships are more likely to take advantage of increased competition, through decreased barriers to entry in the provision of financial services, more precisely, with the proliferation of fintech firms.

\section{Survey Methodology and Descriptive Statistics}

We conduct a survey to analyze the permeation of fintech services in Malaysia. We also gather information on individual savings and credit habits of 2659 participants as well as their use of fintech services. The questionnaire, which is divided into four sections, consists of 32 questions. It covers socio-economic characteristics, use of fintech instruments, barriers to fintech use as well as borrowing and saving practices. We base some of our questions on the Global Findex questionnaire by the World Bank (Demirgüç-Kunt et al., 2018). In addition, we include questions related to fintech service use. Potential respondents cover varied demographics including employees, self-employed individuals, students and unemployed. The survey was administered using an online survey portal, Google forms ${ }^{\circledR}$ by sending the questionnaire link to individuals through social networking sites such as Facebook, WhatsApp and Instagram within a six-week period from 1 October to 10 November 2020. Initially 3000 links were sent, of which 2659 were returned, yielding a response rate of 88.6 percent. We note that a web-based open e-survey is cost-effective, eco-friendly, time-saving and seems to be the most practically feasible mode to conduct surveys during the Covid-19 lockdown period (Srivastav et al., 2021).

\subsection{Survey descriptive statistics: Use of online funding platforms and robo-advisors}

Out of 2659 survey respondents, around $93.5 \%$ or 2486 provide information regarding their use of fintech services. Only 2254 or $84.8 \%$, however, have provided a complete set of information about their socio-economic characteristics, as well as their borrowing or saving practices, and information about their use of online funding platforms and robo-advisors.

We present in Table 1 the descriptive statistics of the percentage of respondents who use fintech services (\%) according to various socio-economic characteristics such as employment status, age, income and education. Majority of our respondents are employed, aged less than 40 years old, with monthly income less than RM4000 (approximately equal to USD1000), and at least have a bachelor's degree.

\section{[nsert Table 1]}

Statistics show that between $26 \%$ and $32 \%$ of the respondents invest in P2P lending and crowdfunding platforms and use robo-advisors. Moreover, we observe variations in fintech use across socioeconomic characteristics. In terms of their employment profiles, employed individuals are more likely to use fintech solutions; around $40 \%$ of the employed invest in P2P lending platforms. This is not surprising as they have more stable financial resources to invest, compared with students and unemployed individuals. Meanwhile, younger respondents use fintech solutions more than their older counterparts, suggesting a digital divide between the young and the old generations, consistent with 
the arguments brought by Choudrie et al. (2018). Moreover, the statistics also show a positive correlation between income levels and the use of fintech services. The poorest individuals are the least likely users of funding platforms and robo-advisors. Middle-income respondents are found to be the main users of fintech services across the three fintech sub-segments. High-income earners are marginally less inclined to invest in online funding platforms and use other fintech services compared with their middle-income counterparts. In addition, there seems to be a positive link between education and the use of fintech services. The percentage of highly educated respondents such as $\mathrm{PhD}$ holders who use these services is at least two times higher than the average across all fintech sub segments. Jünger and Mietzner (2020) present the same findings, indicating greater propensity of individuals with higher education to adopt fintech services. It is important to note, however, that since data collection was conducted online, only individuals with internet access were able to participate in the survey.

Moreover, we observe a positive correlation between the use of various fintech services. We report the correlation matrix between the use of various fintech services in Table 2 . The results suggest that those who invest in P2P lending platforms are also those who may be more likely to use crowdfunding platforms and robo-advisors.

[Insert Table 2]

\subsection{Obstacles to the use of fintech services}

We inquire into the factors deterring fintech service usage across respondents who never used any of the following fintech services - P2P online lending and crowdfunding platforms, and robo-advisors, in the past year. We provide them the following options as plausible reasons: lack of trust, no smartphone, lack of sufficient information, lack of trust, religious reasons, not enough money, already used by family members, and no need for fintech service. We note that respondents may provide multiple answers. We report the survey results in Table 3.

[Insert Table 3]

The survey results indicate that around 58.5\% do not use online P2P lending and crowdfunding platforms and robo-advisors; mostly comprised of students, young adults and respondents with low income, and those with a diploma or a bachelor degree. Aside from not having sufficient resources, not having enough information, lack of trust and no need for them are the three principal reasons behind the hesitation to use fintech services. This is consistent across socio-economic characteristics. Moreover, for students, young adults, low-income earners, they stress lack of money as the main reason why they do not use fintech services. Moreover, it is interesting to note that as the age bracket of the respondents who do not use P2P lending and crowdfunding platforms, and robo-advisors increases, there seems to be an increased hesitation to use fintech services mainly due to lack of trust; for those aged 41-50 years old, they also cited that there's no need for fintech services. Lack of trust has also been cited as a very important obstacle for higher income respondents. On the whole, the survey results seem to suggest that the absence of sufficient information may somewhat play a role in respondents' lack of trust and behind their view that there is no need for fintech services. 


\subsection{Factors considered important in financial services}

We also investigate what respondents deem as the most important factor/s when considering a financial service, differentiated depending on whether they use fintech services or not. We note that the five factors include: trust and reliability, ease of use, type and quality of services provided, financial returns or monetary incentives, and brand prestige. Moreover, respondents can provide multiple answers. We report the survey results in Table 4.

\section{[Insert Table 4]}

The findings show that respondents who invest in P2P lending and crowdfunding platforms and use robo-advisors consider the type and quality of services provided as well as financial returns and ease of use as the most important factors they take into account when considering a financial service. At least $50 \%$ of non-fintech users, on the other hand, cited trust and reliability and ease of use to be the most important factors to consider in a financial service. We also note the big disparity across fintech users and non-fintech users regarding the importance of trust and reliability, ease of use and financial returns or monetary incentives in a financial service. While almost $60 \%$ of non-fintech users treat trust to be a crucial factor, only 35\% of fintech users consider it essential in a financial service. In contrast, we find fintech users, especially those who use robo-advisors and invest in P2P lending platforms, to accord more importance to financial returns compared with non-fintech users. Overall, the survey results seem to suggest that financial returns drive the use of automated, algorithm-driven wealth management services. In contrast, trust and reliability seems to be negatively linked with fintech service use, which is consistent with the survey findings presented in Section 3.2

\subsection{Diversity of saving and borrowing channels and fintech service use}

We present the descriptive statistics of fintech service use according to saving and borrowing channel diversity, as well as differentiate savers and borrowers depending on whether respondents rely on traditional banks or not for their financial services in Table 5.

\section{[nsert Table 5]}

The statistics show differences in proportion of respondents who adopt fintech services according to the diversity of their saving and borrowing channels. While $37-44 \%$ of respondents with multiple saving channels invest in online funding platforms and use robo-advisors, only $16-23 \%$ of non-active savers adopt fintech services, while $24-28 \%$ of those who use single saving channels participate in P2P online lending and crowdfunding, as well as use automated, algorithm driven invest management services. Thus, those with diverse saving channels have higher fintech adoption rates by 16-21 percentage points. We make the same conclusion with regard to borrowing channel diversity. We observe an even larger disparity between respondents with multiple borrowing channels vis-à-vis nonactive borrowers and between those who have access to various borrowing channels vis-à-vis those who rely solely on a specific borrowing conduit. While only $9 \%$ of respondents who did not borrow use robo-advisors, $62 \%$ of those with diverse borrowing conduits use this specific fintech service. Although close to $50 \%$ of those who borrow from a single channel invest in P2P lending platforms, a higher proportion of respondents $(71 \%)$ who have at least two borrowing conduits participate in fintech lending. Moreover, we only observe marginal differences in the proportion of respondents using fintech services according to whether they save in traditional banks or not. Meanwhile, we find 
six out of ten respondents who borrow from traditional banks use also fintech services, while only about $40 \%$ of respondents who do not borrow from banks adopt fintech solutions.

\section{Empirical Methodology and Results}

We use the probit model to investigate whether saving and borrowing practices and socio-economic characteristics are associated with the use of fintech services, more precisely, investment in P2P lending and crowdfunding platforms, and the use of robo-advisors.

\subsection{Do borrowing and saving channel diversities drive the use of fintech services?}

We examine how borrowing and saving channel diversities influence the likelihood of using fintech services. We, hence, address the following questions: Do users of multiple saving and borrowing channels more likely to use fintech services compared with those who rely on a single saving and borrowing channel, and more generally, compared with non-savers and non-borrowers? We purport that, individuals who save through various channels are more likely to perform mental accounting and thus have a higher propensity to use fintech services, such as robo-advisors which facilitate personal investment and wealth management. Moreover, respondents who have multiple saving and borrowing channels are much more likely to take advantage of increased competition, and to consider the services provided by newcomer financial service providers, such as fintech companies, more than those who use single saving, and borrowing channels. Thus, we test Hypothesis 1:

Hypothesis 1: Individuals with multiple saving and borrowing channels are more likely to use fintech services

We hence estimate the following equations (Eq. 1 and 2):

$$
\begin{aligned}
& \operatorname{Pr}\left(\text { fintech_use }_{\mathrm{i}}=1\right)=\Phi\left(\beta_{0}+\beta_{1} \text { singlesaving }_{\mathrm{i}}+\beta_{2} \text { multiplesaving }_{\mathrm{i}}+\sum_{\mathrm{m}=1}^{\mathrm{K}} \gamma_{\mathrm{m}} \mathrm{W}\right) \\
& \left.\operatorname{Pr}_{\text {fintech_use }}=1\right)=\Phi\left(\beta_{0}+\beta_{1} \text {.ingleborrowing }_{\mathrm{i}}+\beta_{2} \text { multipleborrowing }_{\mathrm{i}}+\sum_{\mathrm{m}=1}^{\mathrm{K}} \gamma_{\mathrm{m}} \mathrm{W}\right)
\end{aligned}
$$

Where fintech_use is either p2pinvest, crowdfund or robo-advisor. The variables p2pinvest, crowdfund and roboadvisor are dummy variables which are equal to one if the respondent has invested in P2P lending platforms, participated in crowdfunding platforms, and used robo-advisors in the past 12 months, and zero, otherwise. The saving and borrowing channel diversities are: singlesaving, which is a dummy variable that is equal to one for individuals who use a single saving channel (i.e. traditional banks, cash/gold, or online and mobile banking) and zero, otherwise; multiplesaving is a dummy variable that is equal to one for individuals who have recently used at least two saving channels, and zero, otherwise; singleborrowing is a variable that is equal to one for individuals who have obtained credit either from traditional banks, family/friends, or online banking platforms, in the past 12 months and zero, otherwise; multipleborrowing is a variable that is equal to one for individuals who have obtained credit from at least two sources in the past 12 months, and zero, otherwise. W is a vector of control variables that include individual socio-economic characteristics such as employed, which is equal to one if the individual is an employee or is self-employed and zero if the individual is a student or is unemployed; 
age, which is a discrete variable that is equal to one of the individual is below 21 years old, two if between 21 to 30 years old, three if between 31 to 40, four if between 41 and 50, and five if 51 and above; income, which is a discrete variable that is equal to one of the individual earns below RM 2000 (500 \$), two if the individual earns between RM 2000 and RM 4000, three if between RM 4001 to RM 6000 , and four if above RM 6000; education which is a discrete variable that takes the value of one to six, if the individual's highest educational attainment is secondary school, A-Level, Diploma, Undergraduate degree, Master's, and Doctoral degrees, respectively. To ensure the robustness of our results, we also control for (survey) time and group fixed effects. In these baseline specifications, we note that we study the whole sample of savers and non-savers as well as borrowers and non-borrowers.

We report the estimation results in Table 6. Moreover, we present the predicted probabilities of fintech service use in Table 7, distinguished according to investment in online P2P lending platforms (p2pinvest), in crowdfunding platforms (crowdfund) and use of robo-advisors (robo-advisor) for respondents who use a single saving channel (singlesaving), multiple saving channels (multiplesaving), a single borrowing channel (singleborrowing), multiple borrowing channels (multipleborrowing), as well as for non-savers (non-saver) and non-borrowers (non-borrower).

\section{[Insert Tables 6 \& 7]}

Our findings indicate that those have set aside money or saved recently are more likely to invest in P2P lending and crowdfunding platforms, as well as use robo-advisors than non-savers and nonborrowers. For the latter, they are only $11.5 \%$ to $22.6 \%$ likely to use fintech services. Consistent with our hypothesis, respondents with multiple saving channels are more likely to participate in fintech lending and use automated algorithm-driven wealth management services than their counterparts. Indeed, the likelihood for such respondents to use fintech services is at least $35 \%$, which is about eight to nine percentage points higher than the predicted propensity of those who use single saving channels. Moreover, we observe greater variations in the propensity to use fintech services across respondents with varying borrowing channel diversities. Individuals who were able to obtain credit from at least two channels are more likely to use fintech services than their counterparts. They are at least 40 percentage point more likely to use fintech services than non-borrowers and have higher likelihood to invest and participate in online funding platforms, and use robo-advisors by at least 13.6 percentage points than those who rely on a single borrowing channel. Overall, these findings suggest that individuals who have multiple saving and borrowing channels are more willing and open to use technology-based financial services, as they are more likely to perform mental accounting and budget planning, and at the same time, are more financially savvy to more accurately gauge the value added provided by fintech services. Moreover, our results may also be linked to the survey findings which indicate that lack of enough information, lack of trust and the view that there is no need for these services as main reasons why individuals do not use fintech services. Indeed, we argue that those with multiple borrowing and saving channels are more likely to be up-to-date and have more information about alternative financial solutions, compared with those who solely rely on one channel, and especially those who are not active borrowers and savers.

With regard to individuals' socio-economic characteristics, our findings show that those who are employed, vis-à-vis unemployed individuals, are more likely to use fintech services. Moreover, as age increases, the probability to rely on these relatively new financial service providers decreases. Further, those who have lower monthly revenues are less likely to use fintech services. Meanwhile, more educated individuals are more inclined to invest in P2P lending and crowdfunding platforms and use robo-advisors than those who have lower educational attainment, more particularly for those who 
earned at least a diploma (a level below the attainment of an undergraduate degree). This is consistent with several studies such as Jünger and Mietzner (2020) who find education and financial literacy important in driving fintech adoption and Tun-Pin et al. (2019) whose results show that that younger respondents have higher propensity to use fintech services. Indeed, this may be due to what is called as the 'digital divide' where older generations are less likely to use ICT than the younger generations due to varying reasons such as frustration, non-user-friendly interfaces, mental limits and trust issues (Choudrie et al., 2018).

\subsection{Do borrowing and saving channel diversities drive the use of fintech services? Subsample of savers and borrowers}

To further check the robustness of our results, we investigate only the subsample of savers and borrowers. This allows us to focus on a more homogeneous sample of respondents. The objective is to study the differences in the propensity to use fintech services between borrowers and savers who using single saving and borrowing channels vis-à-vis those who rely on multiple borrowing and saving channels. Consequently, we estimate the following equations:

$$
\begin{aligned}
& \operatorname{Pr}\left(\text { fintech_use }_{\mathrm{i}}=1\right)=\Phi\left(\beta_{0}+\kappa_{1} \text { multiplesaving }_{\mathrm{i}}+\sum_{\mathrm{m}=1}^{\mathrm{K}} \gamma_{\mathrm{m}} \mathrm{W}\right) \\
& \text { Pr(fintech_use } \left._{\mathrm{i}}=1\right)=\Phi\left(\beta_{0}+\kappa_{2} \text { multipleborrowing }_{\mathrm{i}}+\sum_{\mathrm{m}=1}^{\mathrm{K}} \gamma_{\mathrm{m}} \mathrm{W}\right)
\end{aligned}
$$

We present the average marginal effects of relying on a single saving (singlesaving) or borrowing (singleborrowing) channel vis-à-vis using multiple borrowing and saving channels, on the propensity to invest in P2P lending and crowdfunding platforms and use robo-advisors, in Table 8.

\section{[nsert Table 8]}

Our results indicate that among borrowers and savers, those who only rely on one borrowing or saving channel are less likely to use fintech services than those who use at least two channels to save and borrow. Among borrowers, those who obtain credit via a channel are about $11 \%$ less likely to invest in P2P lending and crowdfunding platforms and use robo-advisors than those who use multiple borrowing channels. Moreover, savers who either save or set aside their money only by keeping cash and gold, by relying on online and mobile banking platforms or through financial intermediaries such as banks, are around $8-10 \%$ less likely to use fintech services than those use multiple borrowing and saving channels. Overall, these results confirm the hypothesis that it is more likely for financial service users to adopt fintech services if they rely on multiple saving and borrowing channels.

\subsection{Do respondents who only rely on traditional banks for their saving or borrowing differ from others in terms of the likelihood to use fintech services?}

We further investigate whether the use of specific saving and borrowing channels are linked to fintech service use. For a subsample of savers, we compare the likelihood to use fintech services for those who solely rely on banks vis-à-vis those who rely on different or a combination of saving channels. Moreover, we analyze borrowers' tendencies to invest in P2P lending and crowdfunding platforms and use robo-advisors depending on their existing borrowing channels. We, hence, answer the 
question: do individuals who obtain credit from banks only vis-à-vis those who have existing credit lines from another source or from various sources more or less likely to use fintech services?

More particularly, we examine whether individuals who rely on internal or external financing channels more likely to expand their borrowing and saving relationships to the relatively new fintech service providers. We, hence, test whether it is more likely for individuals who are financially included and rely on formal external saving and borrowing channels to use technology-based financial service.

We thus test the following hypothesis:

Hypothesis 2: Individuals who rely on external borrowing and saving channels are more likely to use fintech services

To test our hypothesis, we estimate the following equations (Eq. 5 and 6) using probit regressions:

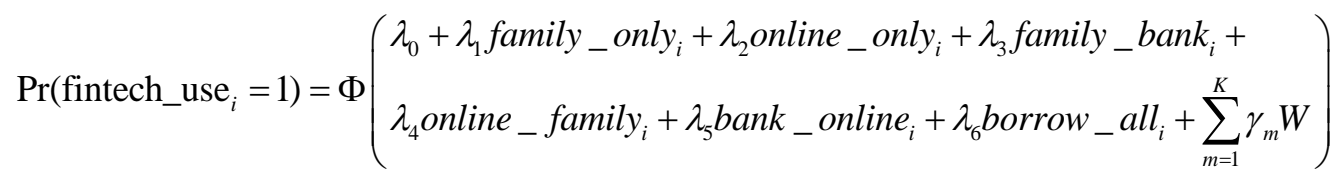

$\operatorname{Pr}\left(\right.$ fintech_use $\left._{i}=1\right)=\Phi\left(\begin{array}{l}\pi_{0}+\pi_{1} \text { save_cashgold }_{i}+\pi_{2} \text { save_online }_{i}+\pi_{3} \text { save_bankcashgold }_{i}+ \\ \pi_{4} \text { save_bankonline }_{i}+\pi_{5} \text { save_cashonline }_{i}+\pi_{6} \text { save_all }_{i}+\sum_{m=1}^{K} \gamma_{m} W\end{array}\right)$

Where fintech_use is either p2pinvest, crowdfund or robo-advisor. The different saving channels are save_cashgold, save_bank, save_online, save_bankcashgold, save_bankonline, save_cashonline, and save_all. save_cashgold is equal to one if respondent $i$ only saved cash or kept gold in the past 12 months, and zero otherwise ; save_online is equal to one if respondent $i$ only saved using online and digital banking platforms and zero, otherwise; save_bankecashgold is equal to one if respondent $i$ saved using two channels: banks and cash/gold ; save_bankonline is equal to one if respondent $i$ saved using banks and digital/mobile banking or online platforms; save_cashonline is equal to one if respondent $i$ saved cash or kept gold and saved in digital banking or online platforms, and zero otherwise; save_all is equal to one if respondent $i$ saved cash, kept gold, saved in banks and in digital/mobile banking or online platforms, and zero, otherwise. The reference group is save_bank which is equal to one if respondent $i$ saved or set aside money using only traditional banks in the past 12 months and, zero, otherwise. W is a a vector of control variables. Moreover, the different borrowing channel indicators are family_only which is a binary variable which is equal to one if respondent $i$ relied and obtained credit only from family members and friends in the past 12 months; online_only is equal to one if respondent $i$ borrowed from online banking platforms in the past 12 months, and zero, otherwise; family_bank is equal to one if respondent $i$ borrowed from family members and banks, and zero, otherwise ; online family is equal to one if respondent $i$ borrowed from family members and online banking platforms and zero, otherwise ; bank_online is equal to one if respondent $i$ borrowed from traditional banks and online banking platforms and zero, otherwise; borrow_all is equal to one if respondent $i$ borrowed from all borrowing channels (family, banks and online/mobile banking platforms) in the past year. The reference group is bank_only, which represents individuals who borrowed only from traditional banks in the past 12 months. 
We present the marginal effects of the specific saving and borrowing channel/s used by respondents in the past year vis-à-vis solely relying on banks on the probability to use fintech services in Table 9 .

\section{[Insert Table 9]}

The findings indicate that those who borrowed only from their family members and friends in the past year are around 27 to $28 \%$ less likely to invest in P2P lending and crowdfunding platforms compared with those who relied only on traditional banks; they are $25 \%$ less inclined to use roboadvisors. Moreover, those who borrowed from traditional banks and online or mobile banking platforms are about $11-15 \%$ more likely to invest in P2P lending and crowdfunding platforms compared with respondents who solely rely on traditional banks. This indicates that reliance on online banking platforms seem to facilitate respondents' participation in online funding platforms. Moreover, we find those who use all borrowing channels to be $15 \%$ more likely to use robo-advisors compared with those who depend only on banks to obtain credit. Overall, the results are consistent with hypotheses 1 and 2. Indeed, reliance on external borrowing channels increases the likelihood of using fintech services, and so is having access to various borrowing channels.

With regard to how specific saving channels affect the likelihood to use fintech services vis-à-vis those who rely solely on banks to save, our findings indicate that those who save cash or keep gold are seven to $12 \%$ more likely to invest in funding platforms and use robo-advisors than those who only have traditional bank savings accounts. Moreover, we also find that those who only save via mobile and online banking platforms to be less inclined to participate in crowdfunding, while those who save in traditional banks and set aside money and have gold to be $8 \%$ more likely to invest in P2P lending platforms compared with those who only save via traditional banks. In addition, we find that the probability to use robo-advisors is higher for those who rely on at least two channels compared with respondents who only possess traditional bank savings accounts. This result provides a concrete evidence of how fintech services, particularly robo-advisors, may enable mental accounting from those who are more likely to perform it. Indeed, those who save using mobile and online banking platforms and set aside cash, as well as those who save using all channels mentioned in the survey, are respectively, $17-18 \%$ and $19 \%$ more likely to use automated, algorithm-driven wealth management services than those who only have savings accounts from traditional banks. Overall, our results confirm hypotheses 1 and 2.

\section{Robustness checks}

We perform several robustness checks. First, we use an alternative discrete variable gauging the degree of fintech service use ranging from non-adoption of fintech lending (P2P online lending and crowdfunding) and robo-advisory services to the use of the three different fintech services. Second, we examine the link between the factors considered crucial in a financial service and the use of fintech services among savers and, third, we assess whether such relationships depend on existing respondent saving channel diversities.

\subsection{Saving and borrowing channel diversity and degree of fintech service use (p2pinvest, crowdfund, robo)}

We examine whether saving, and borrowing channel diversity affect the degree of fintech service use. We empirically analyze this relationship by defining an alternative dependent variable, which measures the degree of fintech service use. We hence define fintech_total, which is a discrete variable ranging 
from zero to three, where zero indicates that a respondent does not use any of the services provided by the three fintech sub-segments (P2P lending, crowdfunding, and robo-advisors), while three indicates that a respondent is an active investor in P2P lending and crowdfunding platforms and is a user of robo-advisors.

We empirically examine the relationship between saving and borrowing channel diversity and the degree of fintech use by using the Poisson regression technique ${ }^{2}$. We present the predicted counts of fintech_total according to the diversity of the saving and borrowing channels of respondents in Appendix A.

The results show a higher predicted count of the degree of fintech use attributed to respondents with multiple saving and borrowing channels compared with their counterparts. Indeed, the predicted degree of fintech use is at least one, if a respondent has multiple saving conduits, compared with only 0.52 and 0.87 for non-savers and those with single saving channels, respectively. Moreover, examining the subsample of savers confirm this finding. In terms of borrowing channel diversity, we find that while the degree of fintech use for non-borrowers is predicted to be equal to 0.37 , the predicted counts of fintech_total for respondents who use single and multiple borrowing channels are 1.23 and 1.56, respectively. This result confirms the results in the baseline specification, thus verifying hypothesis 1. Indeed, individuals with multiple saving and borrowing conduits tend to adopt fintech solutions, and to a stronger degree, compared with their counterparts.

5.2 Do factors which savers consider important in a financial service (trust, ease of use, services, financial incentives, prestige) determine their propensity to use fintech services?

We also analyze whether certain factors individuals consider important in a financial service influence their propensity to use fintech services. We, thus, investigate whether individuals who consider trust and reliability, ease of use, type and quality of services, financial returns or monetary incentives, and brand prestige, to be important elements in a financial service, are more or less likely to use fintech services.

We empirically investigate this issue by estimating the following equation (Eq. 7) using probit regression:

$\operatorname{Pr}\left(\right.$ fintech_use $\left._{\mathrm{i}}=1\right)=\Phi\left(\alpha+\beta\right.$ multiplesaving $\left._{\mathrm{i}}+\sum_{\mathrm{j}=1}^{5} \mathrm{~b}_{\mathrm{j}} \operatorname{imptf}_{\mathrm{ji}}+\sum_{\mathrm{m}=1}^{\mathrm{K}} \gamma_{\mathrm{m}} \mathrm{W}\right)$

Where fintech_use is either p2pinvest, crowdfund or robo-advisor. The saving channel diversity variable, multiplesaving, is a dummy variable equal to one if the respondent uses multiple saving conduits respectively, and zero, if he/she uses a single saving channel. The variables $i_{m p t f}, i m p t f_{2}$, imptf 3 , imptf 4 and $i m p t f_{5}$ represent the factors individuals consider as important in a financial service. imptf, imptf, imptf $_{3}$, imptf 4 and imptf 5 are equal to one if an individual treats trust and reliability, ease of use, type and quality of services, financial returns/monetary incentives and brand prestige as a crucial element in a financial service, respectively, and zero, otherwise. W is a vector of control variables.

\footnotetext{
${ }^{2}$ We do not reject the null hypothesis of equidispersion after performing a test of overdispersion, thus justifying the use of the Poisson regression technique.
} 
We present in Appendix B the average marginal effects of the importance attributed to each factor on the propensity to invest in P2P lending and crowdfunding platforms, and use robo-advisors. We find those who consider trust and reliability important when considering a financial service are, on average, $12 \%, 14 \%$ and $10 \%$ less likely to invest in P2P lending platforms, participate in crowdfunding platforms, and use robo-advisors, respectively, compared with those who do not treat trust to be an important consideration in a financial service. Similarly, we find the attribution of importance on ease of use to be negatively related to the propensity to adopt fintech solutions. The type and quality of services and financial returns, on the other hand, are positively linked with the use of fintech services.

\subsection{Interaction between saving channel diversity and factors savers consider important in a financial service on the propensity to use fintech services}

We show in the previous subsection that while trust, reliability and ease of use are negatively associated with the use of fintech services, factors such as financial returns and the type and quality of services may be positively linked with the use of fintech services. In this section, we distinguish the influence of these key factors on the probability to use fintech services, across savers who use single saving conduits vis-à-vis those who use multiple saving channels. We, hence, differentiate savers with varying saving channel profiles depending on the key factor/s they consider important in a financial service.

To investigate this, we estimate the following equation (Eq. 8) using probit regression:

$\operatorname{Pr}\left(\right.$ fintech_use $\left._{\mathrm{i}}=1\right)=\Phi\left(\alpha+\beta\right.$ multiplesaving $_{\mathrm{i}}+\sum_{\mathrm{j}=1}^{5} \mathrm{~b}_{\mathrm{j}} \operatorname{imptf}_{\mathrm{ji}}+\sum_{\mathrm{j}=1}^{5} \mu_{\mathrm{j}}\left(\right.$ multiplesaving $\left.\left._{\mathrm{i}} *_{\text {imptf }_{\mathrm{ji}}}\right)+\sum_{\mathrm{m}=1}^{\mathrm{K}} \gamma_{\mathrm{m}} \mathrm{W}\right)$

Where fintech_use is either p2pinvest, crowdfund, or robo-advisor. The interaction terms multiplesaving*imptf, multiplesaving*imptf $f_{2}$, multiplesaving*imptf, multiplesaving*imptf $f_{4}$, and multiplesaving*imptf $f_{5}$ are the interactions between the multiplesaving and the variables: imptf $f_{1}$ imptf $f_{2}$, imptf $f_{3}$, imptf $f_{4}$ and $i m p t f_{5}$, respectively.

Figures 1, 2 and 3 show the predicted probabilities of investing in P2P lending platforms, crowdfunding platforms and using robo-advisors according to the variation in the diversity of respondents' saving channels and what they consider as important elements in a financial service. Meanwhile Appendix $\mathrm{C}$ presents the average marginal effects of different financial service elements respondents consider important on the propensity to use fintech services according to the diversity of their saving channels.

[Insert Figures 1, 2 \& 3]

Regardless of whether respondents rely on one or use diverse saving channels, we find those who do not consider trust and reliability as well as ease of use to be important attributes in financial services to have higher likelihood of investing in P2P lending platforms than their counterparts. Moreover, we find a larger gap in the predicted probabilities of investing in P2P lending platforms for those who use multiple saving channels across respondents with varying views in terms of whether trust, reliability, and ease of use are important in a financial service. In addition, we also find those who put a lot of importance on financial returns and monetary incentives when making financial decisions to be more likely to invest in P2P lending platforms; the likelihood seems to be stronger for those who currently use multiple saving channels. This finding suggests that among respondents who use various channels to save, financial returns and not trust nor ease of use drive savers' decision to participate in fintech lending. 
We find similar conclusions in Figure 2, but mainly differ in terms of the importance of financial returns in inciting crowdfunding participation. Indeed, our results indicate that monetary incentives or financial returns do not significantly drive participation of respondents in crowdfunding platforms across respondents who save through a single channel vis-à-vis those who save using multiple channels. Those who consider trust, reliability and ease of use to be important factors in a financial service seem to be more conservative; they are less likely to use fintech services.

Moreover, in terms of the propensity to use robo-advisors to manage wealth and investments, Figure 3 shows that that among respondents who use a single saving channel, those who do not consider trust, reliability and ease of use important in a financial service are $12 \%$ more likely to use roboadvisors than their counterparts. Meanwhile, respondents who use multiple saving channels and who consider financial returns to be an important element in financial decisions are approximately 18\% more likely to use robo-advisors than those who prefer to save via a single channel (i.e. banks, setting aside cash). This implies significant added value brought by automated wealth management services in terms of increased returns, particularly for those who use multiple saving channels who are more likely to perform mental accounting than others. Moreover, respondents who do not treat ease of use and prestige as important considerations in a financial service are more likely to use robo-advisors than their counterparts.

\section{Conclusion}

The main objective of this paper is to examine whether individual borrowing and saving practices, particularly, borrowing and saving channel diversity and reliance on specific borrowing and saving channels, are associated with fintech use. Drawing from the mental accounting concept in behavioral economics, we purport that, individuals who use multiple borrowing and saving channels are more likely to perform mental accounting and narrow bracketing, which is used by fintech firms to facilitate personal wealth management. This may make them more likely to adopt fintech services, such as roboadvisors and online funding platforms. Moreover, as they are exposed to different financial service providers and channels, they are expected to be more adept at gauging the gains from using fintech services. Using online survey responses of around 2000 individuals in Malaysia, our empirical results confirm these hypotheses, even after controlling for respondents' socio-economic characteristics, and after extending the analysis by exploring the impact of borrowing and saving mechanisms on the degree of fintech use. Moreover, we also explore the extent by which factors individuals consider important in a financial service affect the saving channel diversity-fintech use relationship. Across individuals who have multiple saving channels, those who count financial returns important in a financial service, and those who do put less importance on trust and reliability, are the likely users of robo-advisors, and investors in $\mathrm{P} 2 \mathrm{P}$ lending platforms. This finding suggests that lack of trust is a significant barrier toward the use of fintech services. The overall survey results confirm this when respondents were asked about the reasons why they do not use fintech services. On the whole, our paper, which extends the literature on the drivers of fintech adoption, provides important insights and better understanding of the fintech outreach across borrower and saver profiles. Although trust is a main barrier to the use of technology-based financial solutions of fintech companies, some may still be able to derive benefits from fintech approaches if traditional financial institutions adopt innovative solutions, either by providing fintech-inspired solutions or by establishing alliances with fintech firms. 


\section{References}

Abeler, J., Marklein, F. (2017). Fungibility, labels and consumption. Journal of the European Economic Association, 15(1), 99-127.

Buckley, R., Arner, D., Zetzshe, D., \& Veidt, R. (2019). Sustainability, FinTech and Financial Inclusion. In $A$ Research Agenda for Financial Inclusion and Microfinance. https:/ / doi.org/10.4337/9781788114226.00024

Carlin, B., Olafsson, A., Pagel, M., \& Anderson, B. C. (2017). Fintech Adoption Across Generations: Financial Fitness in the Information Age. In NBER working papers (Vol. 23798). http://www.nber.org/papers/w23798\%0Ahttp://www.nber.org/papers/w23798.ack

Cholakova, M., Clarysse, B. (2015). Does the possibility to make equity investments in crowdfunding projects crowd out reward-based investments? Entrepreneurship Theory and Practice, 39(1), 145-172.

Choudrie, J., Junior, C.O., McKenna, B., Richter, S. (2018). Understanding and conceptualising the adoption, use and diffusion of mobile banking in older adults: A research agenda and conceptual framework, Journal of Business Research, 88, 449-465.

Chuang, L., Liu, C., \& Kao, H. (2016). The Adoption of Fintech Service: TAM perspective. International Journal of Management and Administrative Sciences, 3(07), 1-15.

Colombo, M.G., Franzoni, C., Rossi-Lamastra, C. (2015). Internal social capital and the attraction of early contributions in crowdfunding. Entrepreneurship Theory and Practice, 39(1), 75-100.

Costa, A., \& Ehrbeck, T. (2015). A Market-Building Approach to Financial Inclusion. Innovations: Technology, Governance, Globalization, 10(1-2), 53-59. https://doi.org/10.1162/inov_a_00229

D'Acunto, F., Prabhala, N., Rossi, A. 2019. The promises and pitfalls of robo-advising. The Review of Financial Studies, 32(5): 1983-2020.

Daskalakis, N., Yue, W. (2018). User's perceptions of motivations and risks in crowdfunding with financial returns. International Review of Entrepreneurship, 16(3), 1-28.

David, Daniel, and Sade, Orly. (2019). "Robo-Advisor Adoption, Willingness to Pay, and, Trust: An Experimental Investigation.” SSRN. https://papers.ssrn.com/sol3/papers.cfm?abstract_id=3361710

Davis, F.D. (1989). Perceived Usefulness, Perceived Ease of Use, and User Acceptance of Information Technology, MIS Quarterly, 13(3), 319-340.

Davis, F. D., Bagozzi, R., \& Warshaw, P. (1989). User Acceptance of Computer Technology : A Comparison of Two Theoretical Models. Management Science, 35(8), 982-1003. https://doi.org/10.1287/mnsc.35.8.982

Deci, E.L., Ryan, R.M. (2010). Intrinsic motivation. The Corsini Encycopledia of Psychology, 1-2.

Demir, A., Pesqué-cela, V., Altunbas, Y., \& Murinde, V. (2020). Fintech , financial inclusion and income inequality: a quantile regression approach. The European Journal of Finance ISSN:, 1-22. https:// doi.org/10.1080/1351847X.2020.1772335

Demir, T., Mohammadi, A., Shafi, K. (2021). Crowdfunding as gambling: Evidence from repeated natural experiments, Journal of Corporate Finance, https:/ / doi.org/10.1016/j.corpfin.2021.101905.

Demirgüç-Kunt, A., Klapper, L., Singer, D., Ansar, S., \& Hess, J. (2018). The Global Findex Database 2017: Measuring Financial Inclusion and the Fintech Revolution. In The Global Findex Database 2017: Measuring Financial Inclusion and the Fintech Revolution. https://doi.org/10.1596/978-1-4648-1259-0

Fan, L., Chatterjee, S. 2020. The utilization of robo-advisors by individual investors: An analysis using diffusion of innovation and information search frameworks. Journal of Counseling and Planning, 31(1), 130-145.

Fisch, J.E., Labouré, M., Turner, J.A. 2018. The emergence of the robo-advisor. Pension Research Council Working Paper (PRC WP) 2018-12, Pension Research Council, The Wharton School, University of Pennsylvania.

Freedman, S., Jin, GZ. (2017). The information value of online social networks: Lessons from peer-to-peer lending. International Journal of Industrial Organization, 51, 185-222. 
FSB. (2019). BigTech in finance: Market developments and potential financial stability implications, Working Paper, Financial Stability Board, 9 December 2019.

Gan, L.Y., Khan, M.T.I., Liew, T.W. 2021. Understanding consumer's adoption of financial robo-advisors at the outbreak of the COVID-19 crisis in Malaysia. Financial Planning Review, e1127.

Green, D., Liu, E. (2021). A dynamic theory of multiple borrowing. Journal of Financial Economcis, 139: 389-404.

Guidici, G., Guerini, M., Rossi-Lamastra, C. (2018). Reward-based crowdfunding of entrepreneurial projects : The effect of local altruism and localized social capital on proponents' success. Small Business Eocnomics, 50(2), 307-324.

Guirado, C. E., de Ibarreta Zorita, C. M., \& Castro, C. G. (2018). Beyond signed t-shirts: A socio-technological model of equity crowdfunding adoption. Journal of Innovation Economics Management, (2), 137-172.

Hastings, J. S., \& Shapiro, J. M. (2013). Fungibility and consumer choice: Evidence from commodity price shocks. The Quarterly Journal of Economics, 128(4), 1449-1498.

Herzenstein, M., Dholakia, U.M., Andrews, R.L. 2011. Strategic herding behavior in peer-to-peer loan auctions. Journal of Interactive Marketing, 25(1): 27-36.

Hohenberger, C., Lee, C., Coughlin, J.F. 2019. Acceptance of robo-advisors: Effects of financial experience, affective reactions, and self-enhancement motives. Financial Planning Review, 2: e1047.

Hong, C. Y., Lu, X., \& Pan, J. (2020). FinTech Adoption and Household Risk-Taking (No. w28063). National Bureau of Economic Research.

Hu, Z., Ding, S., Li, S., Chen, L., \& Yang, S. (2019). Adoption Intention of Fintech Services for Bank Users: An Empirical Examination with an Extended Technology Acceptance Model. Symmetry, 11(2), 340-356. https://doi.org/10.3390/sym11030340

IMF (2018). The Bali Fintech Agenda: A Blueprint for Successfully Harnessing Fintech's Opportunities. International Monetary Fund, Washington, D.C.

Jaziri, R., \& Miralam, M. (2019). Modelling the crowdfunding technology adoption among novice entrepreneurs : an extended TAM model. Journal of Entrepreneurship and Sustainability Issues, 7(1), 353-374. https://doi.org/10.9770/jesi.2019.7.1(26)

Jünger, M., \& Mietzner, M. (2020). Banking goes digital: The adoption of FinTech services by German households. Finance Research Letters, 34. https:/ / doi.org/10.1016/j.frl.2019.08.008

Lee, E., Lee, B. (2012). Herding behavior in online P2P lending: An empirical investigation, Electronic Commerce Research and Applications, 11(5): pp. 495-503.

Lewis, A. C., Cordero, A. M., \& Xiong, R. (2020). Too Red for Crowdfunding : The Legitimation and Adoption of Crowdfunding Across Political Cultures. Entrepreneurship Theory and Practice, 0(00), 1-34. https://doi.org/10.1177/1042258720915574

Lin, M., Viswanathan, S. (2016). Home bias in online investments: An empirical study of an online crowdfunding market. Management Science, 62(5), 1393-1414.

Lin, M., Prabhala, N., Viswanathan, S. (2013). Judging Borrowers by the Company They Keep: Friendship Networks and Information Asymmetry in Online Peer-to-Peer Lending. Management Science, 59(1): 17-35.

Manrai, L.A., Manrai, A.K. 2007. A field study of customers' switching behavior for bank services, Journal of Retailing and Consumer Services, 14(3), 208-215.

McIntosh, C., Wydick, B. (2005). Competition and microfinance. Journal of Development Economics, 78(2): 271298.

Milkman, K.L., Beshears, J. (2009). Mental accounting and small windfalls: Evidence from an online grocer. Journal of Economic Behavior \& Organization, 71(2), 384-394.

Ozili, P. K. (2018). Impact of digital finance on financial inclusion and stability. Borsa Istanbul Review, 18(4), 329_ 340. https:// doi.org/10.1016/j.bir.2017.12.003 
Philippon, T. (2019). On Fintech and Financial Inclusion (No. w26330). National Bureau of Economic Research.

Pierrakis, Y., Collins, L. (2013). Banking on each other: Peer-to-peer lending to business: Evidence from funding circle, Project Report, NESTA London, U.K.

PwC. (2019). The role of risk and trust in the adoption of risk-advisory in Italy. Pricewaterhouse Coopers Adviosr SpA.

Rabin, M., Weizsäcker, G. (2009). Narrow Bracketing and Dominated Choices, American Economic Review, 99(4), 1508-1543.

Rosavina, M., Rahadi, R. A., Kitri, M. L., Nuraeni, S., \& Mayangsari, L. (2019). P2P lending adoption by SMEs in Indonesia. Qualitative Research in Financial Markets, 11(2), 260-279. https:/ / doi.org/10.1108/QRFM-092018-0103

Saiedi, E., Mohammadi, A., Broström, A., Shafi, K. (2020). Distrust in Banks and Fintech Participation: The Case of Peer-to-Peer Lending, Entrepreneurship Theory and Practice, pp. 1-28. https://doi: $10.1177 / 1042258720958020$.

Senyo, P. K., \& Osabutey, E. L. C. (2020). Technovation Unearthing antecedents to financial inclusion through FinTech innovations. Technovation, June, 102155. https://doi.org/10.1016/j.technovation.2020.102155

Shofawati, A. (2019). The Role of Digital Finance to Strengthen Financial Inclusion and the Growth of SME in Indonesia. The 2nd International Conference on Islamic Economics, Business, and Philanthropy (ICIEBP) Theme: "Sustainability and Socio Economic Growth" KnE Social Sciences, 389-407. https://doi.org/10.18502/kss.v3i13.4218

Singh, S., Sahni, M. M., \& Kovid, R. K. (2020). What drives FinTech adoption? A multi-method evaluation using an adapted technology acceptance model model. Management Decision, 58(8), 1675-1697. https://doi.org/10.1108/MD-09-2019-1318

Srivastav, A. K., Sharma, N., \& Samuel, A. J. (2021). Impact of Coronavirus disease-19 (COVID-19) lockdown on physical activity and energy expenditure among physiotherapy professionals and students using webbased open E-survey sent through WhatsApp, Facebook and Instagram messengers. Clinical Epidemiology and Global Health, 9, 78-84.

Thaker, M., Thaker, H., Rahman, M., Amin, F., Pitchay, A., \& Olaniyi, N. (2019). Factors Affecting Investors' Intention to Invest in A Peer-To-Peer Lending Platform in Malaysia: An Extended Technology Acceptance Model (Issue 998).

Thaler, R.H. (1980). Toward a Positive Theory of Economic Choice. Journal of Economic Behavior \& Organization, 1, 39-60.

Thaler, R.H. (1985). Mental Accounting and Consumer Choice. Market Science, 4(3), 199-214.

Thaler, R.H. (1999). Mental Accounting Matters. Journal of Behavioral Decision Making, 12, 183-206.

Thies, F., Wessel, M., \& Benlian, A. (2016). Personality Matters: How Signaling Personality Traits Can Influence the Adoption and Diffusion of Crowdfunding. Twenty-Fourth European Conference on Information Systems (ECIS), June 2016, Istanbul, Turkey.

Todd, T.M., Seay, M.C. 2020. Financial attributes, financial behaviors, financial-advisor-use beliefs, and investing characteristis associated with having used a robo-advisor. Financial Planning Review, 3(3): e1104.

Tun-Pin, C., Keng-Soon, W. C., Yen-San, Y., Pui-Yee, C., Hong-Leong, J. T., \& Shwu-Shing, N. (2019). An adoption of fintech service in Malaysia. South East Asia Journal of Contemporary Business, Economics and Law, 18(5), 134-147.

Tversky, A., Kahneman, D. (1981). The Framing of Decisions and the Psychology of Choice, Science, 211, 453458.

Xie, J., Latif, Z., Jianqiu, Z., \& Ul Waraa, K. (2019). Analysis of influencing factors of internet lending adoption in China. 13th International Conference on Mathematics, Actuarial Science, Computer Science and Statistics (MACS), 1-8. https://doi.org/10.1109/MACS48846.2019.9024778 
Yang, Q., \& Lee, Y. C. (2016). Critical factors of the lending intention of online P2P: Moderating role of perceived benefit. ACM International Conference Proceeding Series, August 17-19, 1-9. https://doi.org/10.1145/2971603.2971618

Zhang, C.Y., Sussman, A.B. 2018. Perspectives on mental accounting: An exploration of budgeting and investing. Financial Planning Review, 1(1-2) March-June 2018, 1-10. 


\section{TABLES}

Table 1. Percentage (\%) of respondents who use fintech services, according to their socio-economic characteristics

\begin{tabular}{lcccc}
\hline & P2P lending & Crowdfunding & Robo-advisor & \% (sample) \\
\hline All sample & 31.53 & 28.93 & 26.04 & \\
Employment & $(2249)$ & $(2243)$ & $(2254)$ & \\
Self-employed & & & & \\
Employee & 41.85 & 36.16 & 33.71 & 41.53 \\
Student & 39.51 & 38.01 & 32.59 & 37.89 \\
Unemployed & 20.47 & 17.89 & 16.80 & 4.75 \\
Age & 16.19 & 14.02 & 17.76 & \\
$<31$ & & & & 68.41 \\
31-40 & 30.41 & 28.16 & 25.42 & 16.33 \\
41-50 & 39.34 & 34.60 & 33.97 & 9.54 \\
Above 50 & 33.02 & 31.31 & 24.65 & 5.72 \\
Income & 20.16 & 17.97 & 13.18 & \\
Below RM2000 & & & & 40.95 \\
RM2000-4000 & 17.44 & 15.09 & 12.89 & 30.61 \\
RM4001-6000 & 41.84 & 41.05 & 37.97 & 18.81 \\
Above RM6000 & 43.50 & 40.10 & 33.73 & 9.63 \\
Education & 35.48 & 27.78 & 29.03 & \\
Secondary & & & & 9.14 \\
STPM & 21.57 & 19.21 & 19.90 & 7.76 \\
Diploma & 28.57 & 25.71 & 23.43 & 19.03 \\
Bachelor & 29.60 & 29.21 & 25.64 & 5.14 \\
Master & 30.41 & 27.82 & 25.38 & 399 \\
PhD & 53.13 & 45.91 & 38.51 & \\
\hline & 65.79 & 57.89 & 44.74 & \\
\hline
\end{tabular}

Table 2. Correlation between the use of fintech services, all sample

\begin{tabular}{llll}
\hline & P2P lending & Crowdfunding & Robo-advisor \\
\hline P2P lending & 1 & & \\
Crowdfunding & 0.6865 & 1 & \\
Robo-advisor & 0.5853 & 0.5814 & 1 \\
\hline
\end{tabular}


Table 3. Reasons for not using fintech services for a subsample of respondents not participating in online P2P funding platforms and not using robo-advisors (in \%)

\begin{tabular}{lcccccccc}
\hline & $\begin{array}{c}\text { Lack } \\
\text { internet } \\
\text { access }\end{array}$ & $\begin{array}{c}\text { No } \\
\text { smart } \\
\text { phone }\end{array}$ & $\begin{array}{c}\text { Lack } \\
\text { enough } \\
\text { info }\end{array}$ & $\begin{array}{c}\text { Lack } \\
\text { of } \\
\text { trust }\end{array}$ & $\begin{array}{c}\text { Religious } \\
\text { reasons }\end{array}$ & $\begin{array}{c}\text { Not } \\
\text { enough } \\
\text { money }\end{array}$ & $\begin{array}{c}\text { Used by } \\
\text { family } \\
\text { members }\end{array}$ & $\begin{array}{c}\text { No need } \\
\text { for } \\
\text { them }\end{array}$ \\
\hline Sample (1318) & 8.88 & 4.48 & 48.33 & 39.76 & 9.03 & 34.67 & 16.92 & 30.65 \\
Employment & & & & & & & & \\
Self-employed (13\%) & 20.83 & 8.33 & 45.24 & 51.79 & 15.48 & 13.10 & 17.26 & 33.93 \\
Employee (36\%) & 11.49 & 2.34 & 49.79 & 45.74 & 10.85 & 25.53 & 14.47 & 31.70 \\
Student (45\%) & 3.00 & 3.99 & 50.08 & 32.11 & 5.99 & 48.92 & 18.14 & 27.95 \\
Unemployed (6\%) & 12.66 & 12.66 & 32.91 & 36.71 & 7.59 & 26.58 & 21.52 & 37.97 \\
Age & & & & & & & & \\
<31 (70\%) & 3.68 & 3.35 & 50.27 & 34.27 & 5.84 & 43.78 & 15.57 & 28.86 \\
31-40-13\%) & 22.54 & 4.62 & 46.82 & 57.23 & 17.34 & 13.87 & 19.65 & 32.37 \\
41-50 (9\%) & 23.58 & 6.50 & 42.28 & 54.47 & 21.14 & 8.13 & 24.39 & 44.72 \\
Above 50 (8\%) & 15.46 & 12.37 & 40.21 & 42.27 & 9.28 & 18.56 & 15.46 & 26.80 \\
Income & & & & & & & & \\
Below RM2000 (52\%) & 4.35 & 4.06 & 48.55 & 32.61 & 5.51 & 49.42 & 19.13 & 27.83 \\
RM2000-4000 (24\%) & 7.57 & 4.10 & 50.79 & 44.16 & 8.20 & 28.39 & 9.15 & 30.60 \\
RM4001-6000 (15\%) & 21.03 & 4.62 & 46.15 & 52.82 & 20.51 & 8.72 & 24.62 & 37.44 \\
Above RM6000 (9\%) & 18.97 & 7.76 & 43.97 & 48.28 & 12.93 & 7.76 & 12.07 & 36.21 \\
Education & & & & & & & & \\
Secondary (11\%) & 17.12 & 17.12 & 43.15 & 34.93 & 5.48 & 31.51 & 17.12 & 28.08 \\
STPM (8\%) & 20.18 & 4.59 & 54.13 & 52.29 & 21.10 & 23.85 & 19.27 & 32.11 \\
Diploma (19\%) & 10.20 & 3.67 & 38.78 & 39.18 & 12.65 & 32.24 & 17.55 & 34.29 \\
Bachelor (57\%) & 5.44 & 2.12 & 52.39 & 38.73 & 6.23 & 39.52 & 15.92 & 29.71 \\
Master (4\%) & 5.56 & 3.70 & 38.89 & 40.74 & 12.96 & 11.11 & 24.07 & 31.48 \\
PhD (1\%)) & 10 & 20 & 40 & 60 & 30 & 20 & 10 & 30 \\
\hline
\end{tabular}

Table 4. What respondents consider to be important in a financial service, according to use of fintech service

\begin{tabular}{lccccc}
\hline & $\begin{array}{c}\text { Trust/ } \\
\text { Reliability }\end{array}$ & $\begin{array}{c}\text { Ease of } \\
\text { Use }\end{array}$ & Services & $\begin{array}{c}\text { Financial } \\
\text { Incentives }\end{array}$ & Prestige \\
\hline $\begin{array}{l}\text { P2P lending } \\
\text { No }\end{array}$ & 59.26 & 55.23 & 44.38 & 26.19 & 12.74 \\
$\quad$ Yes & 35.17 & 40.25 & 47.74 & 37.57 & 16.81 \\
Crowdfunding & & & & & \\
$\quad$ No & 59.07 & 56.06 & 46.08 & 27.43 & 13.56 \\
$\quad$ Yes & 33.49 & 37.65 & 44.14 & 35.19 & 15.28 \\
Robo-advisors & & & & & \\
$\quad$ No & 57.08 & 55.52 & 44.00 & 26.00 & 13.81 \\
$\quad$ Yes & 36.01 & 36.52 & 49.83 & 40.44 & 14.51 \\
\hline
\end{tabular}


Table 5. Percentage of respondents who use fintech services according their saving and borrowing channel diversities

P2P lending Crowdfunding Robo-advisor

Saving channel

No saving

23.09

16.52

16.41

Single saving channel

27.52

26.92

23.91

Multiple saving channel

44.30

42.31

37.43

Borrowing channel

No credit

12.92

10.30

8.89

Single borrowing channel

49.45

47.39

42.39

Multiple borrowing channel

71.34

68.03

62.31

Savers in banks

No

38.46

35.06

33.72

Yes

33.01

32.63

27.97

Borrowers in banks

No

42.25

39.15

36.72

Yes

67.33

65.39

58.02 
Table 6. Probit regression: Do saving and borrowing channel diversity drive the use of fintech services?

\begin{tabular}{|c|c|c|c|c|c|c|}
\hline & p2pinvest & crowdfund & robo-advisor & p2pinvest & crowdfund & robo-advisor \\
\hline employed & $\begin{array}{l}0.34^{* * *} \\
(3.76)\end{array}$ & $\begin{array}{l}0.38^{* * *} \\
(4.09)\end{array}$ & $\begin{array}{l}0.167^{*} \\
(1.71)\end{array}$ & $\begin{array}{l}0.32^{* * *} \\
(3.35)\end{array}$ & $\begin{array}{l}0.40^{* * *} \\
(3.91)\end{array}$ & $\begin{array}{l}0.153 \\
(1.46)\end{array}$ \\
\hline age $(<21)$ & $\begin{array}{c}1.318^{* * *} \\
(7.41)\end{array}$ & $\begin{array}{c}1.014^{* * * *} \\
(5.38)\end{array}$ & $\begin{array}{c}1.183^{* * * *} \\
(5.96)\end{array}$ & $\begin{array}{c}1.332^{* * *} \\
(6.70)\end{array}$ & $\begin{array}{c}0.967^{* * *} \\
(4.80)\end{array}$ & $\begin{array}{c}1.126^{* * * *} \\
(5.01)\end{array}$ \\
\hline age $(21-30)$ & $\begin{array}{c}0.645^{* * *} \\
(4.06)\end{array}$ & $\begin{array}{c}0.618^{* * *} \\
(3.71)\end{array}$ & $\begin{array}{c}0.699^{* * *} \\
(3.94)\end{array}$ & $\begin{array}{c}0.681^{* * *} \\
(3.77)\end{array}$ & $\begin{array}{c}0.664^{* * *} \\
(3.73)\end{array}$ & $\begin{array}{c}0.723^{* * *} \\
(3.55)\end{array}$ \\
\hline age $(31-40)$ & $\begin{array}{c}0.535^{* * *} \\
(3.35)\end{array}$ & $\begin{array}{c}0.420^{* *} \\
(2.52)\end{array}$ & $\begin{array}{c}0.689^{* * *} \\
(3.89)\end{array}$ & $\begin{array}{c}0.462^{* *} \\
(2.54)\end{array}$ & $\begin{array}{l}0.332^{*} \\
(1.86)\end{array}$ & $\begin{array}{c}0.609^{* * *} \\
(0.203)\end{array}$ \\
\hline age $(41-50)$ & $\begin{array}{c}0.346^{* *} \\
(2.09)\end{array}$ & $\begin{array}{c}0.347^{* *} \\
(1.98)\end{array}$ & $\begin{array}{c}0.394^{* *} \\
(2.13)\end{array}$ & $\begin{array}{l}0.326^{*} \\
(1.74)\end{array}$ & $\begin{array}{c}0.404^{* *} \\
(2.14)\end{array}$ & $\begin{array}{l}0.394^{*} \\
(1.87)\end{array}$ \\
\hline income (RM 2000-4000) & $\begin{array}{l}0.46^{* * *} \\
(4.59)\end{array}$ & $\begin{array}{c}0.53^{* * *} \\
(5.20)\end{array}$ & $\begin{array}{c}0.678^{* * *} \\
(6.22)\end{array}$ & $\begin{array}{c}0.38^{* * *} \\
(3.73)\end{array}$ & $\begin{array}{l}0.45^{* * *} \\
(4.09)\end{array}$ & $\begin{array}{c}0.614^{* * *} \\
(5.32)\end{array}$ \\
\hline income (RM 4001-6000) & $\begin{array}{c}0.62^{* * * *} \\
(5.01)\end{array}$ & $\begin{array}{l}0.63^{* * *} \\
(4.88)\end{array}$ & $\begin{array}{c}0.739^{* * * *} \\
(5.56)\end{array}$ & $\begin{array}{l}0.64^{* * *} \\
(4.98)\end{array}$ & $\begin{array}{l}0.61^{* * *} \\
(4.43)\end{array}$ & $\begin{array}{c}0.702^{* * * *} \\
(4.99)\end{array}$ \\
\hline income (over RM 6000) & $\begin{array}{l}0.48^{* * *} \\
(3.07)\end{array}$ & $\begin{array}{c}0.30^{*} \\
(1.83)\end{array}$ & $\begin{array}{c}0.705^{* * *} \\
(4.46)\end{array}$ & $\begin{array}{l}0.68^{* * *} \\
(4.08)\end{array}$ & $\begin{array}{l}0.45^{* * *} \\
(2.59)\end{array}$ & $\begin{array}{c}0.837^{* * *} \\
(4.91)\end{array}$ \\
\hline education (A-level) & $\begin{array}{c}0.09 \\
(0.59)\end{array}$ & $\begin{array}{c}0.04 \\
(0.25)\end{array}$ & $\begin{array}{c}-0.00268 \\
(-0.02)\end{array}$ & $\begin{array}{c}0.04 \\
(0.24)\end{array}$ & $\begin{array}{c}0.02 \\
(0.09)\end{array}$ & $\begin{array}{c}-0.0713 \\
(-0.42)\end{array}$ \\
\hline education (Diploma) & $\begin{array}{c}0.18 \\
(1.34)\end{array}$ & $\begin{array}{l}0.24^{*} \\
(1.76)\end{array}$ & $\begin{array}{c}0.0855 \\
(0.62)\end{array}$ & $\begin{array}{c}0.21 \\
(1.41)\end{array}$ & $\begin{array}{l}0.30^{* *} \\
(2.02)\end{array}$ & $\begin{array}{l}0.107 \\
(0.73)\end{array}$ \\
\hline education (Undergraduate) & $\begin{array}{l}0.36^{* * *} \\
(2.74)\end{array}$ & $\begin{array}{l}0.31^{* *} \\
(2.33)\end{array}$ & $\begin{array}{l}0.200 \\
(1.48)\end{array}$ & $\begin{array}{l}0.28^{* *} \\
(1.98)\end{array}$ & $\begin{array}{c}0.25^{*} \\
(1.80)\end{array}$ & $\begin{array}{l}0.131 \\
(0.91)\end{array}$ \\
\hline education (Master) & $\begin{array}{c}0.68^{* * *} \\
(4.16)\end{array}$ & $\begin{array}{c}0.56^{* * *} \\
(3.45)\end{array}$ & $\begin{array}{l}0.264 \\
(1.57)\end{array}$ & $\begin{array}{c}0.58^{* * *} \\
(3.35)\end{array}$ & $\begin{array}{c}0.48^{* * *} \\
(2.74)\end{array}$ & $\begin{array}{l}0.168 \\
(0.93)\end{array}$ \\
\hline education $(\mathrm{PhD})$ & $\begin{array}{l}1.18^{* * *} \\
(4.22)\end{array}$ & $\begin{array}{l}0.97^{* * *} \\
(3.35)\end{array}$ & $\begin{array}{l}0.491^{*} \\
(1.81)\end{array}$ & $\begin{array}{l}0.90^{* * *} \\
(3.18)\end{array}$ & $\begin{array}{l}0.71^{* *} \\
(2.48)\end{array}$ & $\begin{array}{l}0.260 \\
(0.93)\end{array}$ \\
\hline singlesaving & $\begin{array}{l}0.32^{* * * *} \\
(3.62)\end{array}$ & $\begin{array}{l}0.59^{* * *} \\
(6.13)\end{array}$ & $\begin{array}{c}0.474^{* * * *} \\
(5.08)\end{array}$ & & & \\
\hline multiplesaving & $\begin{array}{c}0.60^{* * * *} \\
(6.57)\end{array}$ & $\begin{array}{c}0.86^{* * * *} \\
(8.67)\end{array}$ & $\begin{array}{c}0.786^{* * * *} \\
(7.87)\end{array}$ & & & \\
\hline singleborrowing & & & & $\begin{array}{l}1.00^{* * *} \\
(13.28)\end{array}$ & $\begin{array}{l}1.10^{* * *} \\
(13.96)\end{array}$ & $\begin{array}{c}1.061^{\text {**** }} \\
(13.29)\end{array}$ \\
\hline multipleborrowing & & & & $\begin{array}{l}1.46^{* * *} \\
(14.71)\end{array}$ & $\begin{array}{l}1.50^{* * *} \\
(14.94)\end{array}$ & $\begin{array}{l}1.465^{* * *} \\
(14.50)\end{array}$ \\
\hline Time fixed effects & Yes & Yes & Yes & Yes & Yes & Yes \\
\hline Group fixed effects & Yes & Yes & Yes & Yes & Yes & Yes \\
\hline Constant & $\begin{array}{c}-0.72^{* * *} \\
(-3.45) \\
\end{array}$ & $\begin{array}{c}-1.16^{* * *} \\
(-5.31) \\
\end{array}$ & $\begin{array}{c}-1.011^{* * *} \\
(-4.72) \\
\end{array}$ & $\begin{array}{c}-1.10^{* * *} \\
(-5.20) \\
\end{array}$ & $\begin{array}{c}-1.57^{* * *} \\
(-7.19) \\
\end{array}$ & $\begin{array}{c}-1.366^{* * *} \\
(-6.20) \\
\end{array}$ \\
\hline Observations & 2241 & 2235 & 2222 & 2247 & 2241 & 2228 \\
\hline Pseudo $\mathrm{R}^{2}$ & 0.21 & 0.23 & 0.218 & 0.30 & 0.32 & 0.305 \\
\hline Log likelihood & -1100.22 & -1040.02 & -1001.9 & -974.04 & -922.71 & -891.9 \\
\hline $\mathrm{Chi}^{2}$ & $410.37 * * *$ & $435.58 * * *$ & $417.0^{* * * *}$ & $612.30 * * *$ & $626.66^{* * *}$ & $562.2^{* * *}$ \\
\hline
\end{tabular}

T-statistics in parentheses *** $p<.01, * * p<.05, * p<.1$ Variable descriptions: $p 2 p i n v e s t$, crowdfund, and robo-advisor are dummy variables equal to 1 if the respondent invest in $\mathrm{P} 2 \mathrm{P}$ lending platforms, crowdfunding platforms and use robo-advisors, respectively, and zero, otherwise. The variables singlesaving and multiplesaving are dummy variables equal to one if the respondent uses a single saving conduit and multiple saving conduits respectively, and zero, otherwise. The variables singleborrowing and multipleborrowing are dummy variables equal to one if the respondent uses a single borrowing channel and multiple borrowing channels respectively, and zero, otherwise. The control variables include: employed, equal to 1 if the individual is an employee or self-employed and 0 if the individual is a student or is unemployed; age, represents different age tranches: below 21 years old, between 20 to 30 years old, between 31 to 40 years old, between 41 and 50 years old, and 51 and above (reference group); income, represents different income tranches: below RM 2000 (500 \$) (reference group), RM 2000 and RM 4000, between RM 4001 to RM 6000, and above RM 6000; education represents different levels of education: Secondary school (reference group), A-Level, Diploma, Undergraduate degree, Master's, and Doctoral degrees, respectively. To ensure the robustness of results, we also control for (survey) time and group (batch) fixed effects. 
Table 7. Predicted probabilities of the use of online funding platforms according to existing borrowing and saving channels

\begin{tabular}{|c|c|c|c|c|c|c|}
\hline & p2pinvest & crowdfund & robo-advisor & p2pinvest & crowdfund & robo-advisor \\
\hline non-saver & $\begin{array}{l}0.226^{* * *} \\
(0.017)\end{array}$ & $\begin{array}{l}0.162^{* * *} \\
(0.015)\end{array}$ & $\begin{array}{l}0.157^{* * *} \\
(0.014)\end{array}$ & & & \\
\hline singlesaving & $\begin{array}{l}0.311^{* * *} \\
(0.014)\end{array}$ & $\begin{array}{l}0.302^{* * *} \\
(0.014)\end{array}$ & $\begin{array}{c}0.264^{* * *} \\
(0.013)\end{array}$ & & & \\
\hline multiplesaving & $\begin{array}{l}0.395^{* * *} \\
(0.017)\end{array}$ & $\begin{array}{l}0.380^{* * *} \\
(0.017)\end{array}$ & $\begin{array}{l}0.352^{* * *} \\
(0.017)\end{array}$ & & & \\
\hline non-borrower & & & & $\begin{array}{c}0.162^{* * *} \\
(0.011)\end{array}$ & $\begin{array}{c}0.131^{* * *} \\
(0.010)\end{array}$ & $\begin{array}{l}0.115^{* * *} \\
(0.009)\end{array}$ \\
\hline singleborrowing & & & & $\begin{array}{c}0.447^{* * *} \\
(0.018)\end{array}$ & $\begin{array}{c}0.428^{* * *} \\
(0.019)\end{array}$ & $\begin{array}{c}0.385^{* * *} \\
(0.018)\end{array}$ \\
\hline multipleborrowing & & & & $\begin{array}{l}0.600^{* * *} \\
(0.028)\end{array}$ & $\begin{array}{l}0.564^{* * *} \\
(0.029)\end{array}$ & $\begin{array}{l}0.522^{* * *} \\
(0.029)\end{array}$ \\
\hline $\begin{array}{l}\text { singlesaving vs multiplesaving } \\
\text { singleborrowing vs multipleborrowing }\end{array}$ & $-0.084^{* * *}$ & $-0.079^{* * *}$ & $-0.087^{* * *}$ & $-0.153^{* * *}$ & $-0.136^{* * *}$ & $-0.137^{* * *}$ \\
\hline $\begin{array}{l}\text { Delta Standard errors are in parentheses. } \\
\text { are dummy variables equal to } 1 \text { if the } \\
\text { advisors, respectively, and zero, othe } \\
\text { the respondent uses a single saving c } \\
\text { singleborrowing and multipleborrowing are } \\
\text { multiple borrowing channels respecti }\end{array}$ & $\begin{array}{l}p<.01, * * \\
\text { pondent ir } \\
\text { se. The var } \\
\text { luit and } \mathrm{m} \\
\text { nmy varial }\end{array}$ & $\begin{array}{l}05,{ }^{*} p<.1 \\
\text { st in P2P l } \\
\text { les singlesa } \\
\text { ple saving } \\
\text { equal to o } \\
\text { herwise. }\end{array}$ & $\begin{array}{l}\text { ariable descri } \\
\text { ding platform } \\
g \text { and multiple. } \\
\text { onduits respec } \\
\text { if the respor }\end{array}$ & $\begin{array}{l}\text { ons: } p 2 p i n \\
\text { crowdfunc } \\
\text { ing are dun } \\
\text { vely, and } z \\
\text { ent uses a s }\end{array}$ & $\begin{array}{l}\text { crowdfund, } \\
\text { g platforms } \\
\text { y variables } \\
\text { otherwise. } \\
\text { le borrowir }\end{array}$ & $\begin{array}{l}\mathrm{d} \text { robo-advisor } \\
\text { ad use robo- } \\
\text { ual to one if } \\
\text { he variables } \\
\text { channel and }\end{array}$ \\
\hline
\end{tabular}

Table 8. Average marginal effects of having a single borrowing or saving channel vis-à-vis relying on multiple saving and borrowing channels, on the propensity to use fintech services

\begin{tabular}{|c|c|c|c|c|c|c|}
\hline & \multicolumn{2}{|c|}{ p2pinvest } & \multicolumn{2}{|c|}{ crowdfund } & \multicolumn{2}{|c|}{ robo-advisor } \\
\hline & Borrowers & Savers & Borrowers & Savers & Borrowers & Savers \\
\hline singleborrowing & $\begin{array}{c}-.115^{* * *} \\
(.034)\end{array}$ & & $\begin{array}{l}-.114^{* * *} \\
(.035)\end{array}$ & & $\begin{array}{c}-0.116^{* * *} \\
(0.036)\end{array}$ & \\
\hline singlesaving & & $\begin{array}{c}-.079^{* * *} \\
(.024)\end{array}$ & & $\begin{array}{c}-.076^{* * *} \\
(.023)\end{array}$ & & $\begin{array}{c}-0.098^{* * *} \\
(0.023)\end{array}$ \\
\hline
\end{tabular}

Delta Standard errors are in parentheses. ${ }^{* * *} p<.01,{ }^{* *} p<.05,{ }^{*} p<.1$ Variable descriptions: $p 2$ pinvest, crowdfund, and robo-advisor are dummy variables equal to 1 if the respondent invest in P2P lending platforms, crowdfunding platforms and use roboadvisors, respectively, and zero, otherwise. The variable singlesaving is a dummy variable equal to one if the respondent uses a single saving conduit and zero if he/she uses multiple saving conduits. The variable singleborrowing is a dummy variable equal to one if the respondent uses a single borrowing channel and zero if he/she uses multiple borrowing channels. 
Table 9. Average marginal effects of current borrowing and saving mechanism/s vis-à-vis having exclusive saving or borrowing relationships with banks, on the propensity to use fintech services

\begin{tabular}{|c|c|c|c|c|c|c|}
\hline & p2pinvest & crowdfund & robo-advisor & p2pinvest & crowdfund & robo-advisor \\
\hline family_only & $-.273^{* * *}$ & $-.284 * * *$ & $-0.248 * * *$ & & & \\
\hline online_only & $\begin{array}{l}.025 \\
(.043)\end{array}$ & $\begin{array}{l}. .052 \\
(.044)\end{array}$ & $\begin{array}{l}-0.033 \\
(0.044)\end{array}$ & & & \\
\hline family_bank. & $\begin{array}{l}-.082 \\
(.059)\end{array}$ & $\begin{array}{l}-.071 \\
(.063)\end{array}$ & $\begin{array}{l}-0.034 \\
(0.061)\end{array}$ & & & \\
\hline online_family & $\begin{array}{l}-.042 \\
(.063)\end{array}$ & $\begin{array}{l}-.105 \\
(.065)\end{array}$ & $\begin{array}{l}-0.045 \\
(0.069)\end{array}$ & & & \\
\hline bank_online & $\begin{array}{c}.153 * * * \\
(.047)\end{array}$ & $\begin{array}{l}.108^{* *} \\
(.050)\end{array}$ & $\begin{array}{c}0.063 \\
(0.049)\end{array}$ & & & \\
\hline borrow_all & $\begin{array}{l}.057 \\
(.062)\end{array}$ & $\begin{array}{l}.034 \\
(.065)\end{array}$ & $\begin{array}{c}0.148^{* *} \\
(0.064)\end{array}$ & & & \\
\hline save_cashgold & & & & $\begin{array}{c}.119 * * * \\
(.036)\end{array}$ & $\begin{array}{l}.067 * * \\
(.034)\end{array}$ & $\begin{array}{l}0.068^{*} \\
(0.035)\end{array}$ \\
\hline save_onlineonly & & & & $\begin{array}{l}-.023 \\
(.039)\end{array}$ & $\begin{array}{c}-.095^{* *} \\
(.036)\end{array}$ & $\begin{array}{l}-0.047 \\
(0.036)\end{array}$ \\
\hline save_bankcashgold & & & & $\begin{array}{l}.084^{* *} \\
(.038)\end{array}$ & $\begin{array}{c}.027 \\
(.037)\end{array}$ & $\begin{array}{c}0.040 \\
(0.038)\end{array}$ \\
\hline save_bankonline & & & & $\begin{array}{c}.026 \\
(.038)\end{array}$ & $\begin{array}{c}.003 \\
(.036)\end{array}$ & $\begin{array}{c}0.075^{* *} \\
(0.038)\end{array}$ \\
\hline save_cashonline & & & & $\begin{array}{l}.111 * \\
(.062)\end{array}$ & $\begin{array}{c}.063 \\
(.058)\end{array}$ & $\begin{array}{c}0.173^{* * * *} \\
(0.067)\end{array}$ \\
\hline save_all & & & & $\begin{array}{c}.191 * * * \\
(.039)\end{array}$ & $\begin{array}{c}.186 * * * \\
(.038)\end{array}$ & $\begin{array}{c}0.178^{* * *} \\
(0.038)\end{array}$ \\
\hline
\end{tabular}

Delta standard errors in parentheses. ${ }^{* * *} p<.01,{ }^{* *} p<.05, * p<.1$ Variable descriptions: $p 2 p i n v e s t$, crowdfund, and robo-advisor are dummy variables equal to 1 if the respondent invest in $\mathrm{P} 2 \mathrm{P}$ lending platforms, crowdfunding platforms and use roboadvisors, respectively, and zero, otherwise. The saving channels are save_cashgold, save_bank, save_online, save_bankcashgold, save_bankonline, save_cashonline, and save_all. save_cashgold is 1 if an individual only saved cash or kept gold in the past 12 months, and 0 otherwise ; save_online is 1 if an individual only saved using online and digital platforms, and 0 , otherwise ; save_bankcashgold is 1 if an individual saved using 2 mechanisms : banks and cash/gold, and 0, otherwise; save_bankonline is 1 if an individual saved using only two methods, specifically, in banks and in online platforms, and 0, otherwise ; save_cashonline is 1 if an individual saved cash or kept gold and saved in online platforms, and 0 , otherwise; save_all is equal to one if an individual saved cash, kept gold, saved in banks and in online platforms, and 0 , otherwise. The reference group is save_bank which is 1 if an individual saves or sets aside money using only banks and, 0 , otherwise. The borrowing channels are family_only, online_only, bank_only, family_bank, online_family, bank_online and borrow_all. family_only is 1 if an individual relied and obtained credit only from family members and friends in the past 12 months, and 0 , otherwise ; online_only is 1 if individual i borrowed from online platforms in the past 12 months, and 0 , otherwise ; family_bank is 1 if an individual borrowed from family members and banks, and 0 , otherwise ; online_family is 1 if an individual borrowed from family members and online platforms and 0 , otherwise ; bank_online is 1 if an individual borrowed from banks and online platforms and 0, otherwise; borrow_all is 1 if an individual borrowed from all credit sources (family, banks and online platforms) in the past year and 0 , otherwise. The reference group is bank_only, which represents individuals who borrowed only from banks in the past 12 months. 


\section{FIGURES}

Figure 1. Predicted probabilities of investing in P2P lending platforms across saving channel diversity and according to factors respondents consider important in a financial service

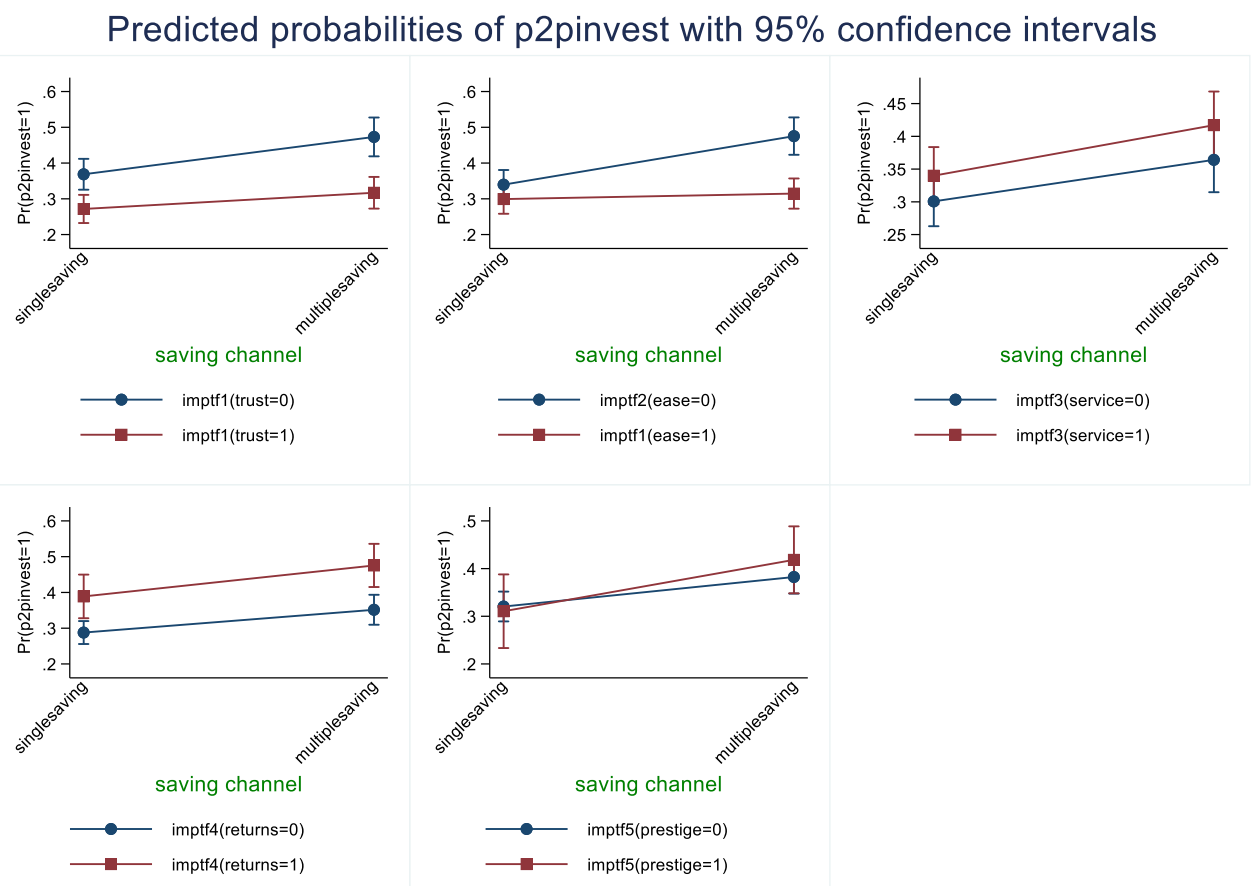

Figure 2. Predicted probabilities of participation in crowdfunding platforms across saving channel diversity and according to factors respondents consider important in a financial service

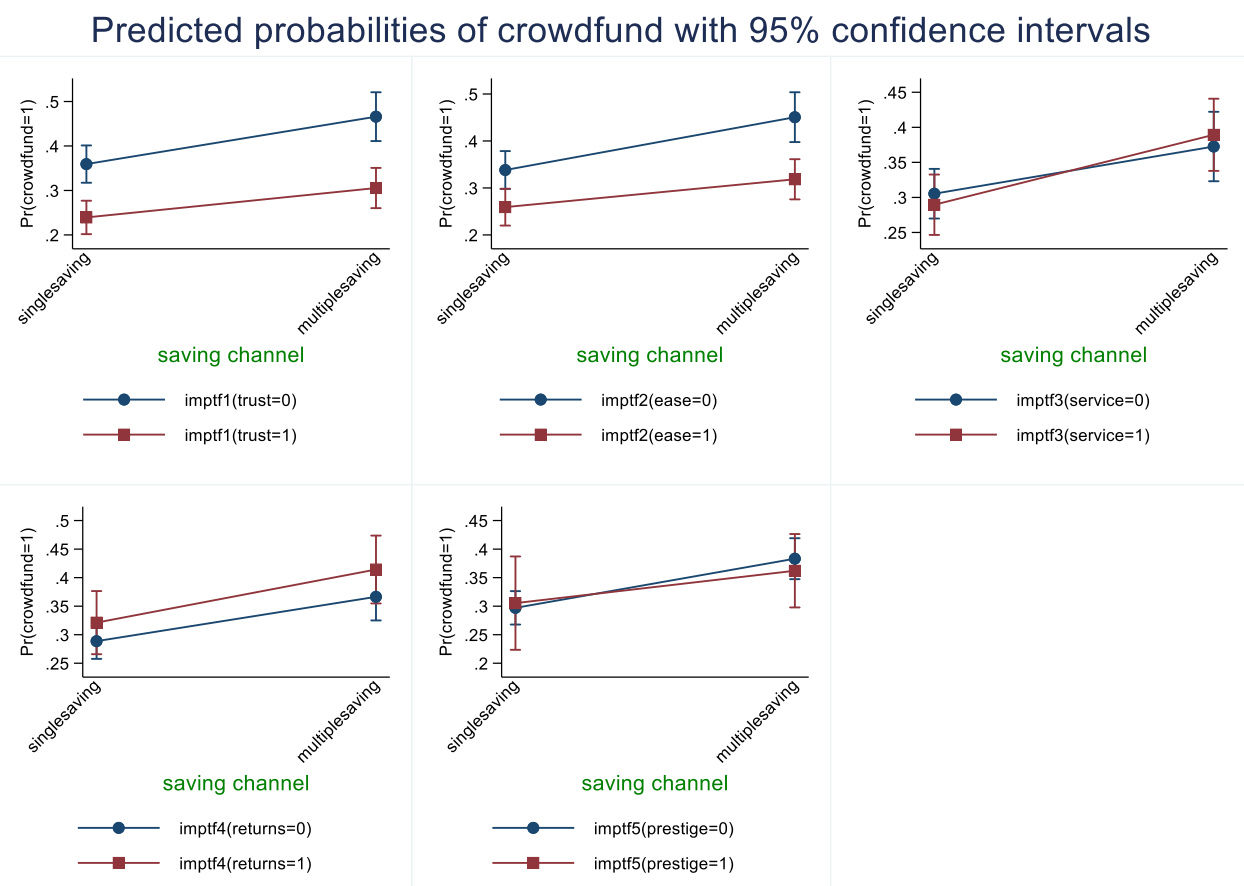


Figure 3. Predicted probabilities of the use of robo-advisors across saving channel diversity and according to factors respondents consider important in a financial service

\section{Predicted probabilities of robo-advisor with $95 \%$ confidence intervals}
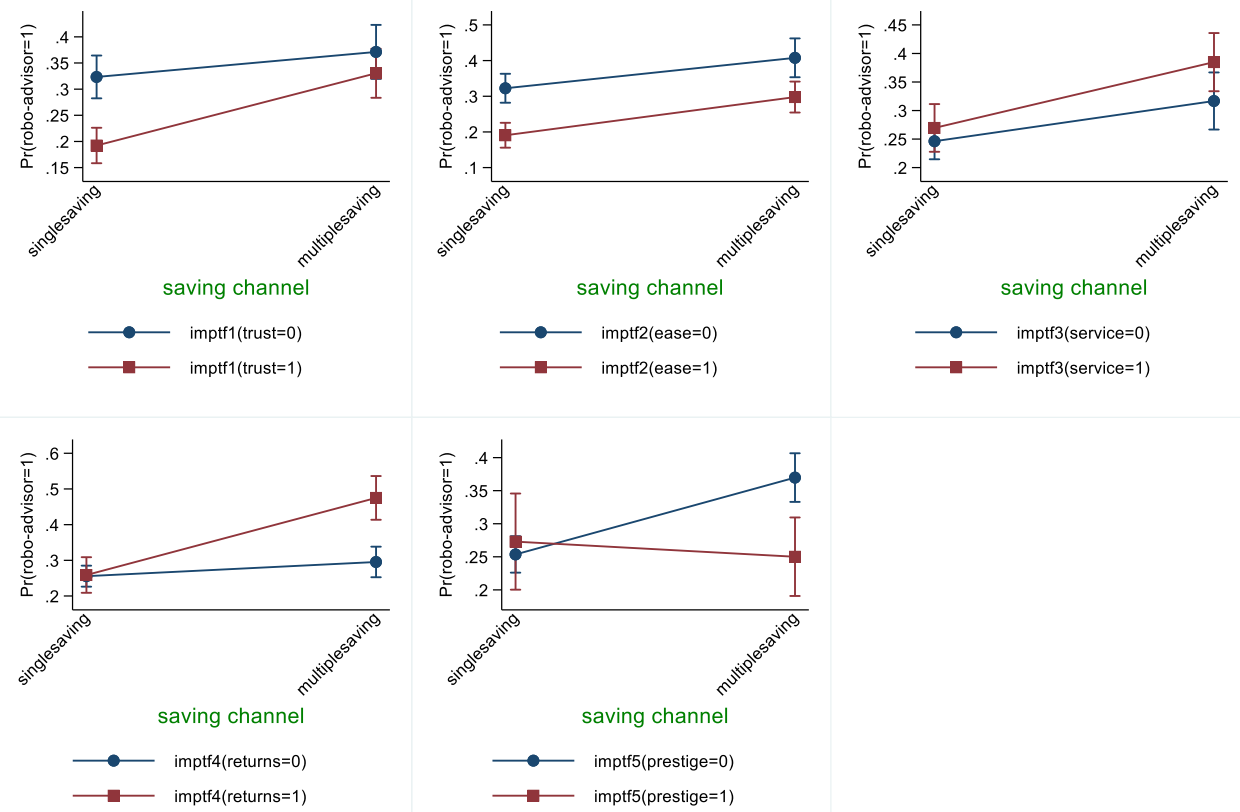


\section{APPENDIX}

Appendix A. Predicted counts of fintech_total according to existing saving and borrowing channels

\begin{tabular}{|c|c|c|c|c|}
\hline & fintech_total & $\begin{array}{l}\text { fintech_total } \\
\text { (savers onlv) }\end{array}$ & fintech_total & $\begin{array}{l}\text { fintech_total } \\
\text { borrowers }\end{array}$ \\
\hline non-saver & $\begin{array}{l}0.524^{* * *} \\
(0.036)\end{array}$ & & & \\
\hline singlesaving & $\begin{array}{l}0.865^{* * *} \\
(0.038)\end{array}$ & $\begin{array}{l}0.839^{* * *} \\
(0.044)\end{array}$ & & \\
\hline multiplesaving & $\begin{array}{l}1.144^{* * *} \\
(0.045)\end{array}$ & $\begin{array}{l}1.129^{* * *} \\
(0.044)\end{array}$ & & \\
\hline non-borrower & & & $\begin{array}{l}0.370^{* * *} \\
(0.022)\end{array}$ & \\
\hline singleborrowing & & & $\begin{array}{l}1.230^{* * *} \\
(0.046)\end{array}$ & $\begin{array}{l}1.466^{* * *} \\
(0.050)\end{array}$ \\
\hline multipleborrowing & & & $\begin{array}{l}1.558^{* * *} \\
(0.069)\end{array}$ & $\begin{array}{l}1.812^{* * *} \\
(0.073)\end{array}$ \\
\hline singlesaving vs multiplesaving & $0.28^{* * *}$ & $0.29^{* * *}$ & & \\
\hline singleborrowing vs multipleborrowing & & & $0.33^{* * *}$ & $0.35^{* * *}$ \\
\hline
\end{tabular}

Delta standard errors in parentheses. fintech_total is a discrete variable corresponding to the sum of p2pinvest, crowdfund, and robo-advisor, which are dummy variables which take the value of 1 if a respondent invests in P2P lending platform, participate in crowdfunding platforms, and use robo-advisors, respectively, and zero, otherwise. The variables non-saver and non-borrower are dummy variables equal to 1 if the respondent did not save and borrow in the past 12 months, respectively. The variables singlesaving and multiplesaving are dummy variables equal to one if the respondent uses a single saving conduit and multiple saving conduits respectively, and zero, otherwise. The variables singleborrowing and multipleborrowing are dummy variables equal to one if the respondent uses a single borrowing channel and multiple borrowing channels respectively, and zero, otherwise.

Appendix B. Average marginal effects of the factors respondents consider important in a financial service (among savers) on the propensity to use fintech services (invest in P2P lending platforms, participate in crowdfunding platforms and use robo-advisor services)

\begin{tabular}{lccc}
\hline & p2pinvest & crowdfund & robo-advisor \\
\hline imptf $_{\text {: }}$ Trust \& Reliability & $-0.121^{* * *}$ & $-0.136^{* * *}$ & $-0.093^{* * *}$ \\
imptf : Ease of use & $(0.023)$ & $(0.023)$ & $(0.023)$ \\
& $-0.088^{* * *}$ & $-0.100^{* * *}$ & $-0.119^{* * *}$ \\
imptf : Type \& Quality of Services & $(0.022)$ & $(0.022)$ & $(0.022)$ \\
& $0.041^{*}$ & -0.005 & $0.050^{* *}$ \\
imptf : Financial returns & $(0.024)$ & $(0.023)$ & $(0.023)$ \\
& $0.114^{* * *}$ & $0.041^{*}$ & $0.078^{* * *}$ \\
imptf : Brand prestige & $(0.026)$ & $(0.024)$ & $(0.023)$ \\
& 0.016 & -0.007 & $-0.052^{* *}$ \\
\hline
\end{tabular}

Delta standard errors in parentheses. ${ }^{* *} p<.01,{ }^{* *} p<.05,{ }^{*} p<.1$ Variable descriptions: $p 2 p i n v e s t$, crowdfund, and roboadvisor are dummy variables equal to 1 if the respondent invest in $\mathrm{P} 2 \mathrm{P}$ lending platforms, crowdfunding platforms and use robo-advisors, respectively, and zero, otherwise; imptf $f_{1}, i m p t f_{2}$, imptf $f_{3}, i m p t f_{4}$, and $i m p t f_{5}$ are dummy variables equal to 1 if the respondent consider trust and reliability, ease of use, type and quality of services, financial returns, and brand prestige as an important factor to consider in a financial service, respectively, and zero, otherwise. 
Appendix C. Average marginal effects of features in financial services respondents consider important on the propensity to use fintech services (Use of Single Saving Channel vs. Use of Multiple Saving Channels)

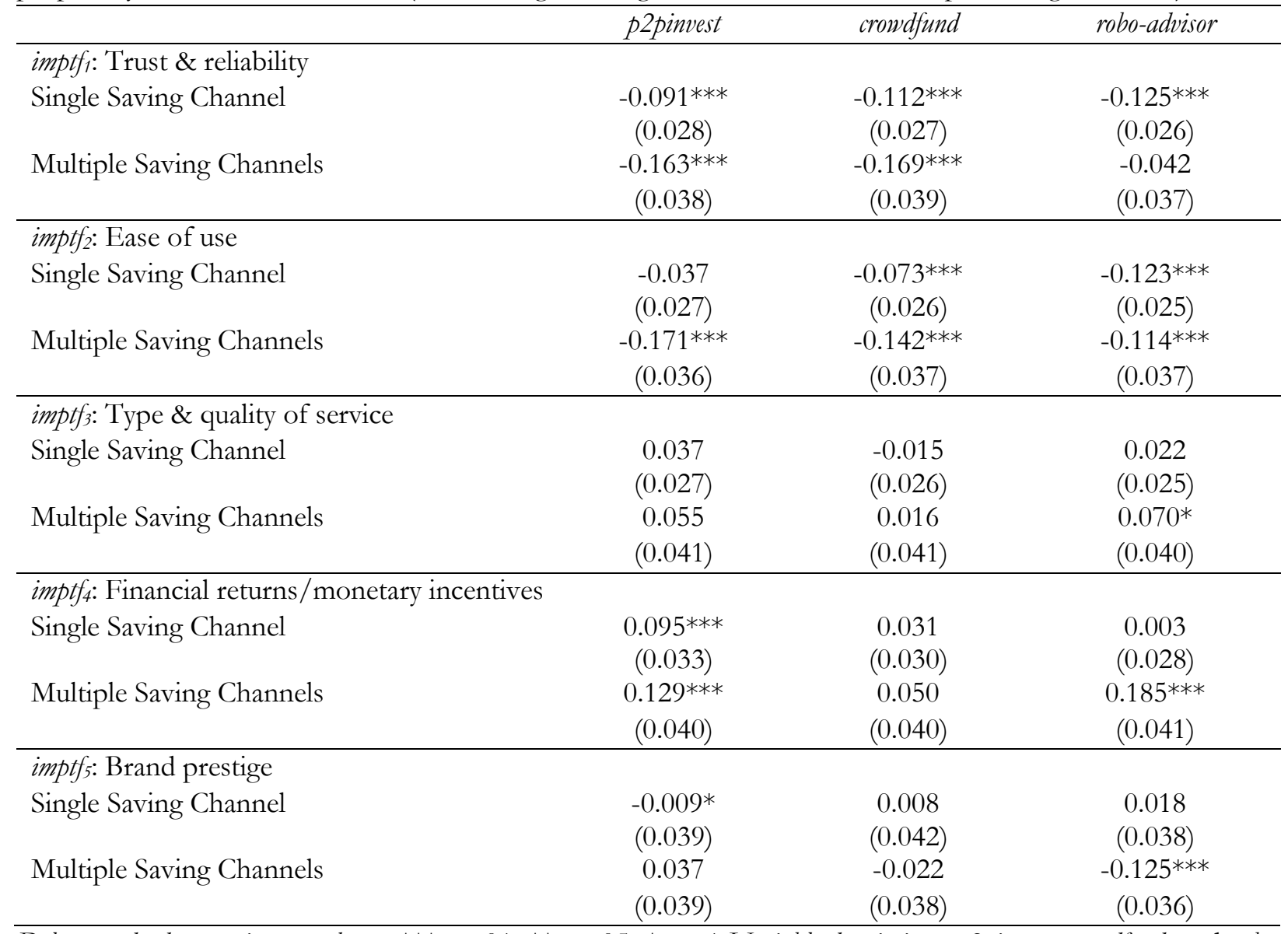

Delta standard errors in parentheses. ${ }^{* * *} p<.01,{ }^{* *} p<.05, * p<.1$ V ariable descriptions: $p 2$ pinvest, crowdfund, and roboadvisor are dummy variables equal to 1 if the respondent invest in P2P lending platforms, crowdfunding platforms and use robo-advisors, respectively, and zero, otherwise; imptf $f_{1}$, imptt $f_{2}$, imptf $f_{3}, i m p t f_{4}$, and $i m p t f_{5}$ are dummy variables equal to 1 if the respondent consider trust and reliability, ease of use, type and quality of services, financial returns, and brand prestige as an important factor to consider in a financial service, respectively, and zero, otherwise. 